\title{
New Upper Carboniferous palynofloras from Southern Pyrenees (NE Spain): Implications for palynological zonation of Western Europe
}

Manuel A. Juncal ${ }^{\mathrm{a}, *, 1}$, Joan Lloret $^{\mathrm{b}, *, 1}$, José B. Diez ${ }^{\mathrm{a}}$, José López-Gómez ${ }^{\mathrm{c}}$, Ausonio Ronchi ${ }^{\mathrm{b}}$, Raúl De la Horra ${ }^{d}$, José F. Barrenechea ${ }^{c}, e$, Alfredo Arche $^{\mathrm{C}}$

a Departamento de Xeociencias M. e O.T., Facultade de Ciencias do Mar, Universidade de Vigo, Campus As Lagoas - Marcosende, E-36310 Vigo, Spain

b Dipartimento di Scienze della Terra e dell'Ambiente, Università degli studi di Pavia, Via Ferrata 7, 27100 Pavia, Italy

C Instituto de Geociencias (UCM, CSIC), C/ Doctor Severo Ochoa 7, E-28040 Madrid, Spain

d Departamento de Geodinámica, Estratigrafía y, Paleontología, Facultad de Geología, Universidad Complutense de Madrid, C/ José Antonio Nováis 12, E-28040 Madrid,

Spain

e Departamento de Mineralogía y Petrología, Facultad de Geología, Universidad Complutense de Madrid, C/ José Antonio Nováis 12, E-28040 Madrid, Spain

Keywords: Palynomorph Gzhelian Stephanian Autunian Pensylvannian

A B S T R A C T

In the western European basins, the paleoflora of late Pennsylvanian-early Permian transition is still a matter of discussion in terms of its age determination and biostratigraphic ranges. This study represents a review of the Upper Carboniferous and Permian stratigraphy of the Central and Eastern Pyrenees from continental successions with interbedded volcanic-volcaniclastic rocks, coupling new palynological data and known palynological as- semblages to calibrate them with recent SHRIMP U-Pb zircon ages dates obtained in previous works. In this light, the first continental unit overlying the Variscan basement bears a Gzhelian palynological association, which fits perfectly with the isotopic SHRIMP U-Pb zircon dating of the associated pyroclastic rocks $(304.6 \pm 1.5 \mathrm{Ma}$ and $300.4 \pm 1.4 \mathrm{Ma})$.

In order to provide a solid base to characterize the Carboniferous-Permian microflora evolution in the western Tethys sub-basins, we have compared radiometrically dated palynological assemblages of the Euramerican Province such as Spain, southern France, the Alps and Sardinia (Italy). The new biostratigraphic and chronos- tratigraphic information presented here confirms the validity of the classical Carboniferous Palynological Zonation of Western Europe. 


\section{Introduction}

The Late Pennsylvanian (306.7-298.9 \pm 0.15 Ma, Ogg et al., 2016) and Permian (298.9 \pm 0.15-251.902 $\pm 0.024 \mathrm{Ma}$, Lucas and Shen, 2018) were characterized by the intense changes involved in the early tectonic post-assembly of the Pangea supercontinent and its breakup after the Variscan orogen climax (Ziegler et al., 1979; Simancas et al., 2005; Isozaki, 2009).

The first part of this period (Late Pennsylvanian-early Permian) is considered to be an interval of geological and climatic transition. Deposits of coal, laterite and bauxite, indicative of humid tropical pa- laeoclimatic conditions, were replaced by signs of more aridity such as the presence of Vertisols and calcretes and aeolian and evaporite de- posits (Tabor and Poulsen, 2008). Large variations in the concentration of atmospheric $\mathrm{CO} 2$ and $\mathrm{O} 2$ have also been registered for this period(e.g. Beerling et al., 2002; Berner et al., 2007; Montañez et al., 2007, 2016; Royer, 2014). All these changes occurred as a result of the trend toward global warming that followed the PermoCarboniferous glacial retreat (Fielding et al., 2008).

The overall trend toward Carboniferous-Permian aridification in the Euramerican Biota Province has been described as a climatic transition from tropical everwet to sub-humid during early Cisuralian and to semi- arid during the last part of this period (Roscher and Schneider, 2006; Tabor and Poulsen, 2008; Michel et al., 2015). This progressive ar- idification reached its maximum around the Kungurian-Wordian age (late Cisuralian-early middle Guadalupian) and the climate continued as seasonal and dry during the late Guadalupian, across the PermoTriassic Boundary and even in the Early Triassic (Schneider et al., 2006; Montañez et al., 2007; Tabor and Poulsen, 2008; Gulbranson et al., 2015; Michel et al., 2015).

The climatic change observed during the Late Pennsylvanian- Permian produced an increase in the extinction rates of land plants (Cascales-Miñana and Cleal, 2014). The influence of aridification during this time is directly reflected by the variations in the constitution and distribution of floral associations (Ziegler, 1990; Kerp, 1996; DiMichele et al., 2001b; Wagner, 2004a; Schneider et al., 2006). In fact, in the Euramerican Province, this period has been interpreted as the "collapse of the rainforests" (DiMichele et al., 2009; Cleal et al., 2010, 2011; Sahney et al., 2010; Gulbranson et al., 2015). The replacement of hygrophytic ("Stephanian flora") by mesophytic and mesoxerophytic floras ("Autunian flora") that tolerated a seasonally dry climate has been documented. Conifers and other gymnosperms adapted to drier conditions and propagated progressively (e.g. DiMichele et al., 2001a; Looy et al., 2014) to become a dominant element in the landscapes until the Mesozoic.

In the Euramerican Province, the continental vegetation during the Pennsylvanian was a hygrophilous flora comprising pteridosperms, marattialean ferns, lycopsids, Calamites and Cordaites trees (DiMichele et al., 2006; Thomas and Cleal, 2017). In the Late Pennsylvanian-early Permian, "Carboniferous hygrophilous flora" proliferated in the wet depressions (lowlands). Mesophilic or even meso-xerophytic flora, whose most remarkable components were walchian conifers (Lemoigne and Doubinger, 1984) grew outside these areas (uplands), in dewatered habitats where the environmental conditions became less favourable for "Stephanian elements" (Broutin et al., 1986). This change in the flora was not isochronous across the Euramerican Province (e.g. Bouroz and Doubinger, 1977; Wagner, 1984; Broutin et al., 1990a, 1990b; Kerp, 1996; Blake et al., 2002). The early appearance of "Autunian flora" in Carboniferous rocks has been reported in outcrops from Western Europe (e.g. Lemoigne and Doubinger, 1984; Broutin and Gisbert, 1985; Broutin et al., 1986; Doubinger and Roy-Dias, 1985; Broutin et al., 1990a, 1990b; DiMichele and Aronson, 1992; Kerp and Flchter, 1985; Martín-Closas and Galtier, 2005; Gand et al., 2013). Conversely, taxa from a Carboniferous-type wetland biome, interpreted as stream- and lake-side elements (DiMichele et al., 2006; Gand et al., 2013), re- appear in early Permian landscapes dominated by conifers (Broutinet al., 1990a; Galtier and Broutin, 1995). 
Records of Permian "mixed flora", including elements from more than one Palaeo-kingdom, may also appear in these above-cited environments (e.g. Broutin, 1986; Broutin et al., 1990b; Berthelin et al., 2003, 2006; Broutin and Berthelin, 2005; Sun, 2006; Cleal, 2016). This complex scenario was also affected by the phytogeographical provinciality that had a negative effect on the precise correlation between regional palynostratigraphic schemes (Stephenson, 2016).

Recently, two different lines of approach have emerged to shed some light on this problematic transition. The first is the isotopic SHRIMP U-Pb zircon dating (e.g. Pereira et al., 2014; Michel et al., 2015; Pellenard et al., 2017); the second is the new palynological data presented in this work. We combine the results of the two-pronged chronostratigraphic information to characterize the Carboniferous- Permian transition in the western Tethys subbasins, reviewing the age of the rocks and comparing our results with the best known microfloral associations in the western Peri-Tethys region.

\section{Background and geological setting}

In the western European basins, the Late Pennsylvanian-early Permian transition is mainly represented by fluvio-lacustrine deposits with sequences of coal seams and bituminous shales frequently inter- bedded with volcaniclastic products (Cassinis et al., 2000, 2003; Bruguier et al., 2003; Schneider et al., 2006; Gand et al., 2013; Pereira et al., 2014; Michel et al., 2015; Luthardt et al., 2016; Opluštil et al., 2016a, 2016b, 2017; Pellenard et al., 2017). The radiometric dating of those volcanic and volcaniclastic rocks provides an important tool for correlating palynological associations with absolute ages. Correlating the age of microflora with other geochronological data (e.g. U-Pb dating, conodonts, macroflora, tetrapods footprints) would allow us to discern and validate the Palynological Zonation of Western Europe for the Late Carboniferous (Clayton et al., 1977). In order to precise the correlation of the Late Carboniferous-early Permian continental suc- cessions in the southwestern of Europe (eastern Equatorial Euramerica or western Tethys), it is essential to improve our knowledge of the

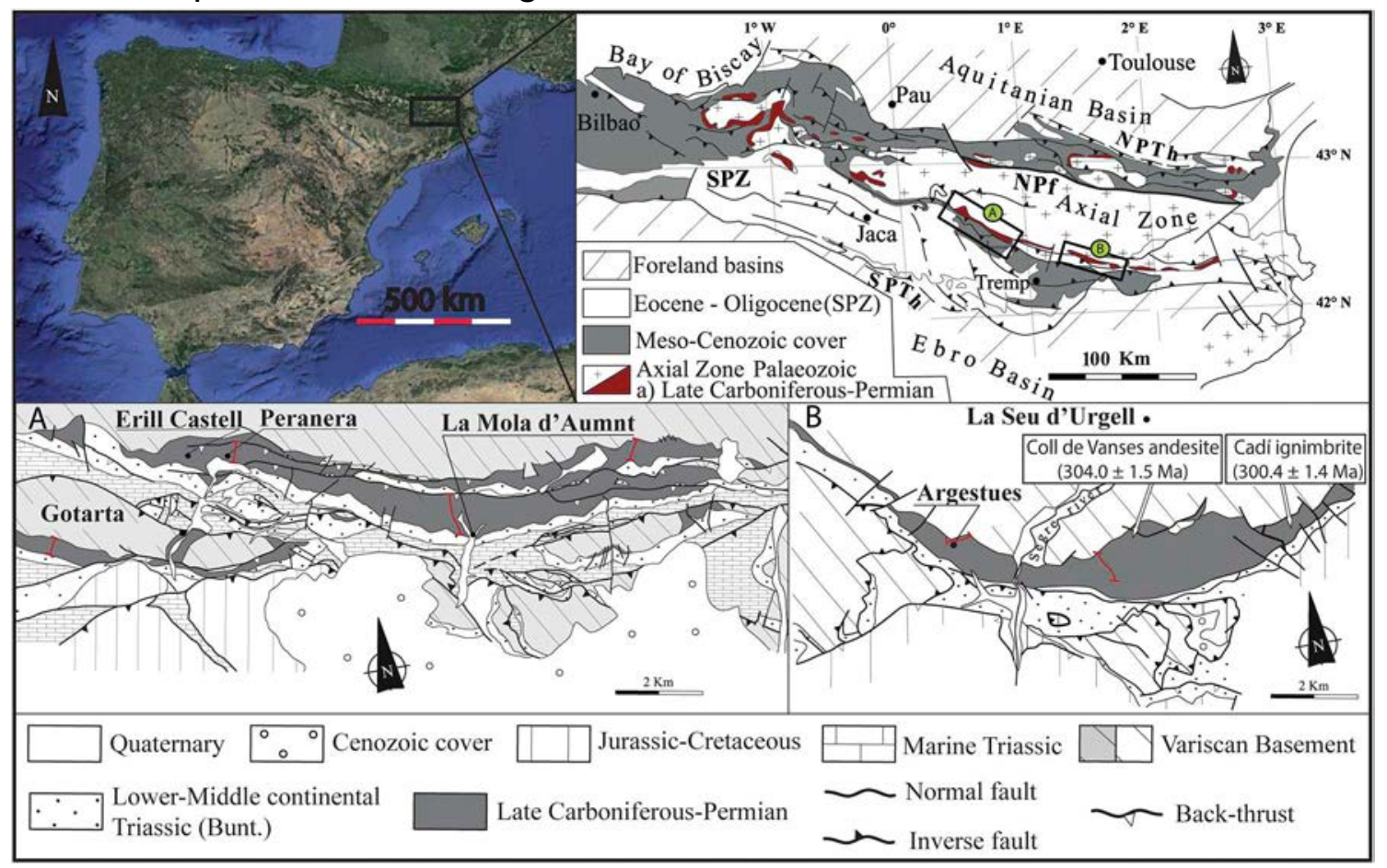

Fig. 1. Geographical and geological situational map of Iberia and the Late Carboniferous and Permian basins in the Pyrenees. A: Detailed geological map of Erill Castell Basin. The red line represents the site of the studied sections. B: Detailed geological map of Gramós Basin. The 
red line represents the site of the studied sections. (For interpretation of the references to colour in this figure legend, the reader is referred to the web version of this article.) 
palynological associations of this period and to understand the sig-nificance of the unconformities and hiatuses present in the Post-Var- iscan deposits, which are important in the correlation of basins (Cassinis et al., 2012; Gretter et al., 2015).

The Pyrenean late Palaeozoic successions are located in the Axial zone of the Pyrenees and were the result of continental transtensive- extensive basins created during the initial phase of the Pangea breakup (Soula et al., 1979; Gisbert, 1981; Bixel and Lucas, 1983; Martí, 1986). These basins have been described as half-graben structures (Soriano et al., 1996; Saura and Teixell, 2006), which created a complex system of isolated or partly interconnected sub-basins (Gisbert, 1981, 1983; Gretter et al., 2015). Initially, the stratigraphic record was strongly affected by volcanism and widespread syn-sedimentary tectonic ac- tivity. Large andesite sheets and ignimbritic bodies are interbedded at various levels with the sedimentary infill (Martí, 1986; Mitjavilla and Molist, 1988; Gretter et al., 2015), and several faults defined the mor- phology of the basins (Fig. 1A, B; Soriano et al., 1996; Saura and Teixell, 2006). Until the absolute ages recently obtained by Pereira et al. (2014), the chronostratigraphic subdivision of these basins was palaeontologically assigned and subject to debate (Dalloni, 1930; Mey et al., 1968; Nagtegaal, 1969; Gisbert, 1981, 1983). The poor pa- laeontological content of the Permian red beds, mainly based on tet- rapod footprints (Robles and Llompart, 1987; Mujal et al., 2016a, 2016b, 2017), has not been sufficient to establish a precise age for all the units.

Four lithostratigraphic units delimited by unconformities (Fig. 2) have been defined (Gisbert, 1981) for the latest Carboniferous-Permian time-interval. From base to top these are: a) Grey Unit (namely Aguiró Fm. and Erill Castell Fm. of Mey et al., 1968; Nagtegaal, 1969); b)Transition Unit (corresponding to the top of Erill Castell Fm. and Malpàs Fm. of Mey et al., 1968; Nagtegaal, 1969); c) Lower Red Unit, and d) Upper Red Unit (Peranera Fm. of Mey et al., 1968; Nagtegaal, 1969).

In the studied area, the succession starts with the Grey Unit, com- prising basal breccias with thin interbedded coal seams (Aguiró Fm.). Going upward, it is mostly composed of volcanic and volcaniclastic rocks. The last part of the succession is composed by conglomerates, sandstones, siltstones and coal deposits. There are several remains of Pennsylvanian macroflora in these coal layers (Asturian-Stephanian C in age) in the Aguiró, Argestues, Malpás, Surroca, Ogassa, and Coll de Sas localities (Table 1). The radiometric ages proposed by Pereira et al. (2014) from intrusive and extrusive lava sheets for the basal Grey Unit in Coll de Vanses andesite and Cadí ignimbrite (Fig.1b) led to the as- signation of the basal Grey Unit (Aguiró Fm.) to the Kasimovian $(307.4 \pm 1.4 \mathrm{Ma})$. Similarly, the upper portion of this unit (Erill Castell Fm.) has been assigned to an early Gzhelian age (304.6 $\pm 1.5 \mathrm{Ma}$ and

$300.4 \pm 1.4 \mathrm{Ma}$; Pereira et al., 2014). It is noteworthy that the strati- graphic position of these absolute datations is located several meters below the aforementioned coal levels.

The Transition Unit ("Unidad de Tránsito" of Gisbert, 1981 and "Permien alternant" of Broutin et al., 1994) is characterized by volcanic levels (mainly andesites), intercalated volcaniclastics, conglomerate, sandstones and siltstone beds that include "late Stephanian-Autunian flora" (Table 1). The radiometric ages in the Estac ignimbrite of the basal part of this unit endorse an Asselian age $(296.2 \pm 3.1 \mathrm{Ma}$,

$296.1 \pm 4.0 \mathrm{Ma}$; Pereira et al., 2014).

The Lower and Upper Red units consist of red bed successions composed of reddish conglomerates, sandstones and siltstones. These 


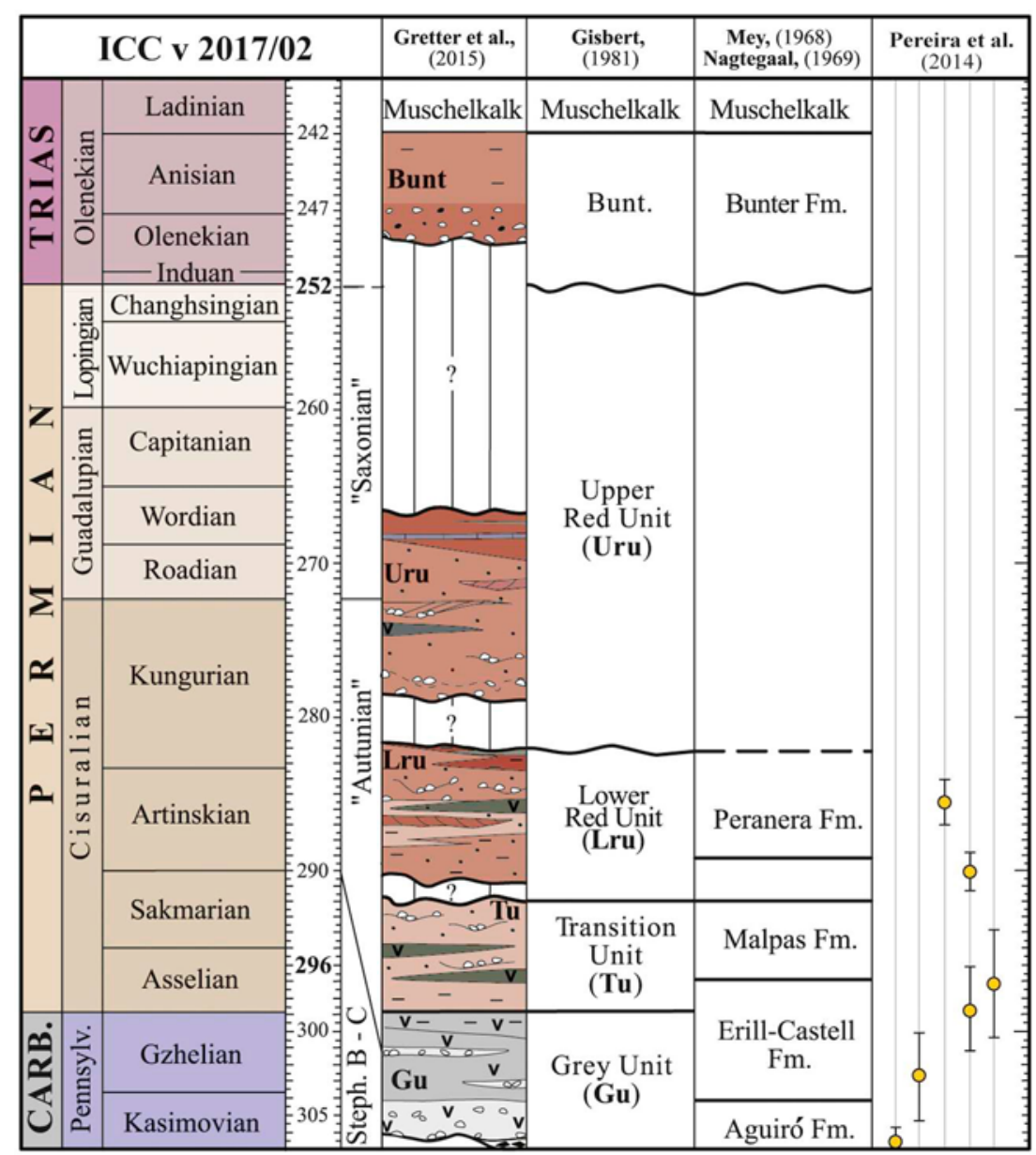

Fig. 2. Chronostratigraphy of the continental successions of the Southern Pyrenean basins. Modified from Gretter et al. (2015) and Lloret et al. (2018). 
Table 1

Compilation of the palaeontological record of the Late Carboniferous-Permian basins in the Central-Eastern Southern Pyrenees.

\begin{tabular}{|c|c|c|c|}
\hline Campodrón & Lower Red Unit & “Autunian” (Early Permian) & Broutin and Gisbert (1985) \\
\hline Gotarta & Lower Red Unit & “Autunian” (Early Permian) & Broutin and Gisbert (1985) \\
\hline \multirow[t]{2}{*}{ Arcalis } & Transition Unit & “Autunian” (Early Permian) & Talens and Wagner (1995) \\
\hline & & “Autunian” (Early Permian) & Schmidt (1931) \\
\hline \multirow[t]{2}{*}{ Baró } & Transition Unit & Early Permian & Álvarez-Ramis (1985) \\
\hline & & “Autunian” (Early Permian) & Menéndez Amor (1952) \\
\hline \multirow[t]{2}{*}{ Coll de Jou } & Transition Unit & $\begin{array}{l}\text { "Middle-Upper Autunian” (late } \\
\text { Gzhelian) }\end{array}$ & Wagner and Álvarez-Vázquez (2010) \\
\hline & & Stephanian B-C & Broutin and Gisbert (1985) \\
\hline Coll de la Caritat & Transition Unit & Late Stephanian & Broutin and Gisbert (1985) \\
\hline \multirow[t]{4}{*}{ Malpás } & Transition Unit & Stephanian C & Wagner and Álvarez-Vázquez (2010) \\
\hline & (Malpás Fm) & Late Stephanian C - "lower & Talens and Wagner (1995) \\
\hline & & Autunian” (Early Permian) & \\
\hline & & Stephanian & Dalloni (1930); Nagtegaal (1969) \\
\hline Estac & Uncertain & “Early Autunian” (Early Permian) & Álvarez-Ramis and Doubinger (1987) \\
\hline Rio Pallarols/Gotarta & Grey Unit & Gzhelian & This Study \\
\hline Coll de Sas & Grey Unit & Stephanian C & Mujal et al. (2018) \\
\hline \multirow[t]{6}{*}{ Surroca/Ogassa } & Grey Unit & Stephanian C & $\begin{array}{l}\text { Álvarez-Ramis et al. (1971); Doubinger et al. (1978); Doubinger and Álvarez-Ramis } \\
\text { (1984); Martín-Closas and Martínez-Roig (2007); Wagner and Álvarez-Vázquez } \\
\text { (2010) }\end{array}$ \\
\hline & & Late Stephanian & Dalloni (1930); Álvarez-Ramis et al. (1969); Álvarez-Ramis (1985) \\
\hline & & Middle Stephanian & Jongmans (1951) \\
\hline & & Stephanian (Surroca) - Late & Faura (1914) \\
\hline & & Stephanian (Ogassa) & \\
\hline & & Upper Carboniferous & Faura (1913) \\
\hline ErillCastell/Malpás & $\begin{array}{l}\text { Grey Unit (Erill Castell } \\
\text { Fm) }\end{array}$ & Cantabrian (Stephanian A) & Dalloni (1930); Talens and Wagner (1995) \\
\hline Argestues & Grey Unit (Aguiró Fm) & Stephanian B & Broutin and Gisbert (1985) \\
\hline \multirow[t]{4}{*}{ Aguiró } & Grey Unit (Aguiró Fm) & Asturian (Westphalian D) & Wagner and Álvarez-Vázquez (2010) \\
\hline & & $\begin{array}{l}\text { Late Westphalian-Cantabrian } \\
\text { (Stephanian A) }\end{array}$ & Talens and Wagner (1995) \\
\hline & & Westphalian D & Nagtegaal (1969) \\
\hline & & Middle-Upper Westphalian & Dalloni (1930) \\
\hline
\end{tabular}

Tetrapod's footprints and bones

Pla de St. Tirs/Noves de SegreUpper Red Unit "Late Permian" Robles and Llompart (1987)

Noves/La Trava Upper Red Unit ?Middle Permian (Wordian) Mujal et al. (2016a) Coll de Terrers Upper Red

Unit "Late Permian" Mujal et al. (2018)

La Mola d'Amunt Lower Red Unit Middle-Late early Permian

(Artinskian)Mujal et al. (2016b)

two red units are separated by an angular unconformity (Gisbert, 1983; Gretter et al., 2015). The age of these units is still a subject of debate. Nevertheless, tetrapod footprints from the Lower Red Unit would sug- gest an Artinskian age (Mujal et al., 2016a, 2016b), and the radiometric dating in the Castellar de N'Hug area obtained by Pereira et al. (2014) indicates 283.4 \pm 1.9 Ma age. The finding of a caseid vertebra (sy- napsids group) from the uppermost part of the Upper Red Unit by Mujal et al. (2016a, 2017) did not yield any chronostratigraphic constraints, but a middle Permian age can be considered for this unit, based on regional correlation and facies comparison (Gretter et al., 2015).

The Late Pennsylvanian-early Permian palaeontological data from the Catalan Pyrenees has been described by previous authors in two main areas (Fig. 1). The central Pyrenees include the areas of Erill Castell, Malpás, Baró, Arcalis, Coll de Sas, Gotarta and Estac (Dalloni, 1930; 
Schmidt, 1931; Menéndez Amor, 1952; Nagtegaal, 1969; Álvarez-Ramis, 1985; Talens and Wagner, 1995; Wagner and Álvarez- Vázquez, 2010; Mujal et al., 2018). The main sections in the eastern Pyrenees are Ogassa, Surroca, Coll de Jou, Coll de la Caritat and Camprodón (Faura, 1913, 1914; Dalloni, 1930; Jongmans, 1951; Álvarez-Ramis et al., 1969, 1971; Doubinger et al., 1978; Doubinger and Álvarez-Ramis, 1984; Broutin and Gisbert, 1985; Wagner, 2004b; GómezAlba, 2007; Martín-Closas and Martínez-Roig, 2007; Wagner and Álvarez-Vázquez, 2010). In both areas, the precise characterization of the Permo-Carboniferous transition is a challenge, due to the poorpreservation of palynological remains and because some studies were preliminary in its palynological and stratigraphic interpretations (Broutin and Gisbert, 1985), or the location of the palynological sam- ples was uncertain (Álvarez-Ramis and Doubinger, 1987).

\section{Materials and methods}

This work involves a palynological and stratigraphic review of the Late Carboniferous and Permian successions of the Central and Eastern Pyrenees. On the basis of the established stratigraphic division (Gisbert, 1981), we logged and sampled the Grey Unit in six different locations of the Erill Castell (Fig. 1A) and Gramós (Fig. 1B) basins. The stratigraphic loggings were made using standard physical parameters such as li- thology, sedimentary structures and thicknesses (Figs. 3, 4). Only Rio Pallarols and Gotarta sections provided positive palynological samples: Pall1, PL-02 and PL-06 (Rio Pallarols) and GT-2 (Gotarta).

The Grey Unit palynological assemblage was obtained from PL-02 and Pall-1 samples from the Argestues locality (Rio Pallarols, Fig. 3). The PL-06 sample association was discarded due to its poor preserva- tion and low taxonomic diversity. Similarly, the organic matter from the GT-02 sample was highly altered even though the same taxa are observed. Preservation and taphonomy constraints prevented a quan- titative study of samples. Therefore, we studied all the samples as the same "assemblage", which provided the first palynological 


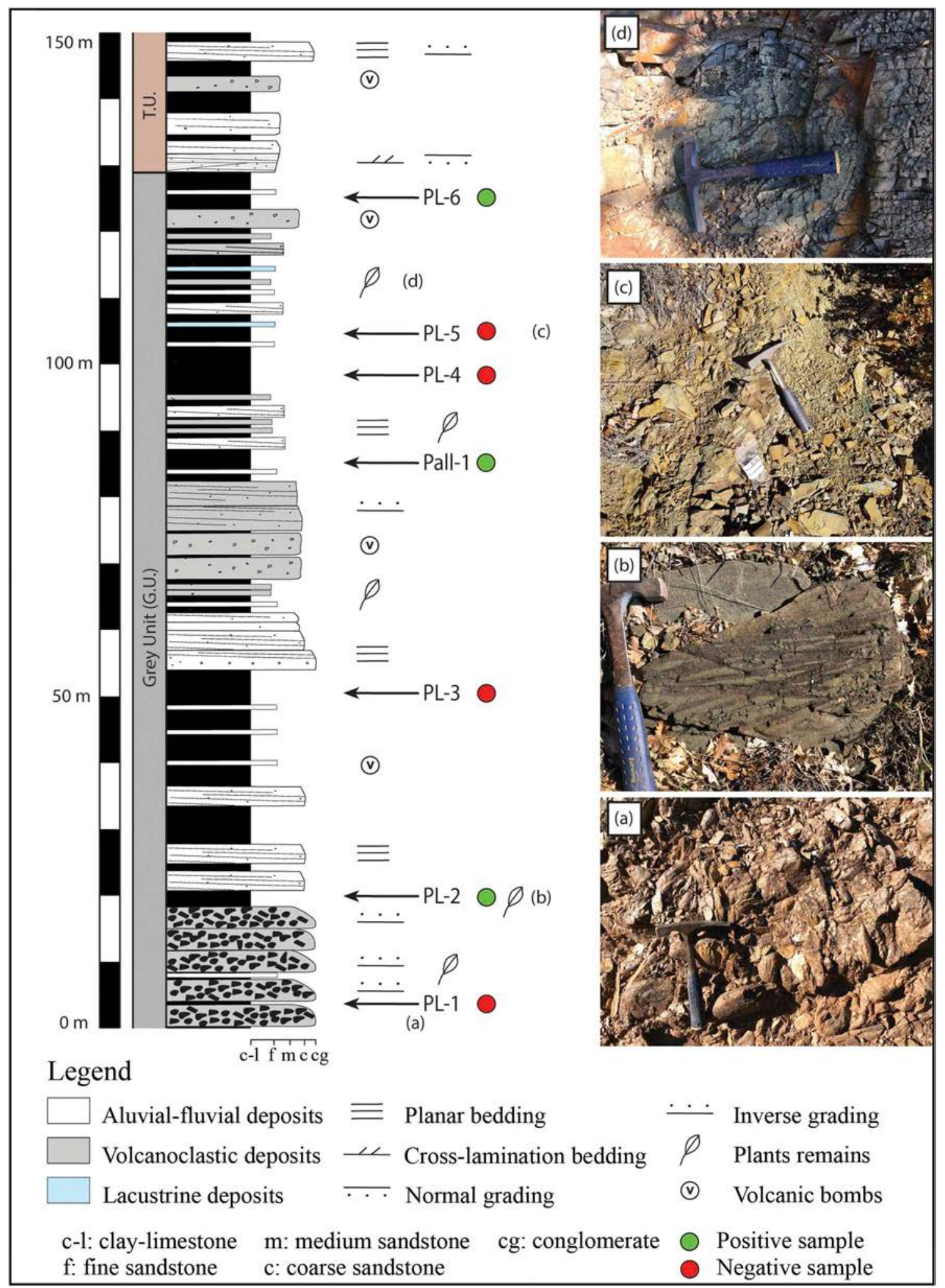

Fig. 3. Stratigraphic log of Rio Pallarols section placed in Gramós Basin (Fig. 1B). A: Basal conglomerate with rounded basement clasts corresponding to Palaeozoic. B: Plants remain. C: Materials where was collected the sample PL-5. D: Trunk fossil.

characterization for the Grey Unit.

The samples were processed in the laboratory of the Geosciences Department at the University 
of Vigo, using maceration procedures ( $\mathrm{HCl}-\mathrm{HF}-\mathrm{HCl}$ techniques) followed those outlined by Erdtman (1943), Wood et al. (1996) and Traverse (2007). The samples were processed by first adding $\mathrm{HCl}$ and HF to remove carbonate and silicate minerals. No oxidising treatment was used, due to the fragility of the palynomorphs. A dispersing agent was subsequently added to facilitate filtering and sieving at $10 \mu \mathrm{m}$. The palynological slides were analyzed in the Mi- croscopy Labs at the University of Vigo with a Leica DM 2000 LED and the photos were taken with a Leica ICC50 W camera magnified $\times 1000$. 


\section{Results}

\subsection{Stratigraphy and sedimentology}

Two stratigraphic sections were studied in detail: the Argestues section and the Gotarta section.

In the Argestues section (Fig. 3) the four lithostratigraphic units of the latest Carboniferous and Permian defined by Gisbert (1981) are well exposed. The first deposits comprised polygenic breccia with Devonian carbonates and Silurian schists clasts (Fig. 3A). The clasts are 10-15 cm in size and are often imbricated with poor vertical gradation. Moving upward, the breccias yield to channelised conglomerate bodies with erosive basal surfaces constituting fining-upward sequences 2-5 $\mathrm{m}$ thick with thin coal horizons and $2-5 \mathrm{~cm}$ thick greyish claystone levels at the top. The PL-2 sample was collected from a dark, thick claystone levels where several plant fragments with a variable grade of conservation were found (Fig. 3B). The general thinning and fining-upward trend of this first part of the Grey Unit has been interpreted as distal alluvial fans in the base, evolving to more developed fluvial systems in its topmost parts (Gisbert, 1981, 1983). Moving upward, the section consists of beds $10-30 \mathrm{~cm}$ thick and up to $10 \mathrm{~m}$ wide, constituted by medium- coarse greyish sandstones with low angle trough cross-bedding inter- bedded with thin beds of greyish siltstones with horizontal laminations and $20-30 \mathrm{~cm}$ thick coal levels at the topmost part. The sample Pall-1 was collected in the finest upper part of these deposits.

The middle-upper part of the Argestues section is composed of finer grey sediments corresponding to alluvial-fluvial deposits associated with low-gradient fluvial systems with widespread overbank deposits (Fig. 3C). The uppermost part of the Grey Unit in the Argestues section was highly influenced by volcanic activity and contains reworked ochre tuffs and middle-size sandstone levels with cross-laminations. One im- portant characteristic of this interval was the presence of life-position petrified trunks, up to $20-30 \mathrm{~cm}$ in diameter (Fig. 3D), with annualgrowth-rings still preserved. Volcanic bombs larger than $20 \mathrm{~cm}$ and lapilli deposits were interbedded at the top, with alternating levels of greyish sandstones and siltstones with 5-10 cm thick coal beds. The sample PL-6 was collected in the grey siltstones placed near the boundary with the Transition Unit.

The Gotarta section (Fig. 4) is represented by the Grey, Transition and Lower Red units. The stratigraphic record begins with the basal breccias of the Grey Unit composed of sub-rounded clasts of Silurian and Devonian rocks. Above it, there are outcrops of volcaniclastic de- posits with tuffs and bombs of up to $30 \mathrm{~cm}$ in size (Fig. 4A). These deposits pass up gradually to reworked sandstones with cross-bedding stratification, and plant remains that are overlaid by tabular carbonate beds of less than $10 \mathrm{~cm}$ thick (Fig. 4).

The upper part of the Grey Unit in the Gotarta section is represented by medium-coarse grained volcaniclastic deposits with a fining-upward general trend followed by sandstones and siltstones of ephemeral fluvial systems (Gisbert, 1981; Gretter et al., 2015). The GT-2 sample was collected at thin-dark levels intercalated in the finer upper deposits (Fig. 4B, C). The topmost part consisted of intercalated laminated fine sandstones, and red claystones of fluvio-lacustrine origin and lacustrine deposits (Gisbert, 1981, 1983) with badly preserved plant remains.

\subsection{Palynology}

A palynological assemblage has extracted from the Grey Unit (Figs. 5 and 6):

Acanthotriletes echinatus (Knox) Potonié and Kremp 1955.

Acanthotriletes tenuispinosus Naumova 1953. Angulisporites splendidus Bharadwaj 1954.

Apiculatisporis microacanthus Andreyeva 1956. Apiculatisporis parvispinosus (Leschik) 
Schulz 1962. Calamospora breviradiata Kosanke 1950.

Calamospora microrugosa (Ibrahim) Schopf, Wilson and Bentall 1944.

Calamospora pedata Kosanke 1950.

Cirratriradites rarus (Ibrahim) Schopf, Wilson and Bentall 1944.

Cyclogranisporites microgranus Bharadwaj 1957. Deltoidospora adnata (Kosanke) McLean

1993. Deltoidospora priddyi (Berry) McGregor 1973. Deltoidospora sphaerotriangula (Loose)

Ravn 1986. Florinites junior Potonié and Kremp 1956.

Florinites mediapudens (Loose) Potonié and Kremp 1955.

Granulatisporites granulatus Ibrahim 1933. Granulatisporites minutus Potonié and

Kremp 1955. Granulatisporites microgranifer Ibrahim 1933.

Laevigatosporites perminutus Alpern 1958. Laevigatosporites vulgaris (Ibrahim) Ibrahim

1933. Latensina trileta Alpern, 1958.

Lophotriletes microsaetosus (Loose) Potonié and Kremp 1955.

Lundbladispora gigantea (Alpern) Doubinger 1968.

Potonieisporites novicus Bhardwaj 1964. Potonieisporites simplex Wilson 1962.

Punctatosporites minutus Ibrahim 1933. Punctatosporites punctatus Ibrahim 1933.

Savitrisporites camptotus (Alpern) Doubinger 1968.

Vesicaspora wilsonii (Schemel) Wilson and Venkatachala 1963. Vestispora cf. cancellata

(Dybová and Jachowicz) Wilson and Venkatachala 1963.

Chromotriletes sp. Dictyotriletes sp. Endosporites sp. Guthoerlisporites sp.

Lundbladispora sp. Maculatasporites sp. Nuskoisporites sp.

Plicatipollenites sp. Potonieisporites sp. Spinosporites sp.

Wilsonites sp. Unidentified disaccites.

\section{Discussion}

To date, only two palynological studies have been performed in the Late Carboniferous-lower Permian succession of the Central-Eastern Pyrenees (Broutin and Gisbert, 1985; Álvarez-Ramis and Doubinger, 1987). In the first of these (Broutin and Gisbert, 1985), a "Stephanian- Autunian flora" from Argestues, Coll de Jou, Coll de la Caritat, Vehinat de Fogonella and Gotarta (Lleida, Spain) was reported. In the Vehinat de Fogonella Outcrop (Campodrón locality), a preliminary palynolo- gical assemblage was obtained between two volcanic levels in the basal section of the Lower Red Unit: Costapollenites ellipticus, Potonieisporites bhardwaji, Potonieisporites novicus, Vittatina fasciolata, Cordaitina sp., Gardenasporites sp. and Florinites sp. This assemblage presents "Autu- nian characteristics" due to the presence of monosaccate pollen to- gether with striated taxa, which indicates a younger age than the Grey Unit assemblage described in this study. Therefore, the association described by Broutin and Gisbert (1985) is consistent with the Artins- kian age of the Lower Red Unit (283.4 $\pm 1.9 \mathrm{Ma})$ provided by Pereira et al. (2014) in the Southern Pyrenees.

In the second study (Álvarez-Ramis and Doubinger, 1987), from an uncertain outcrop of fossiliferous shales a microflora obtained from fossiliferous shales was described with the following taxa: Florinites mediapudens, Granulatisporites cf. parvus, Guthoerlisporites magnificus, Laevigatosporites vulgaris, Leiotriletes adnatus (= Deltoidospora adnata), Lundbladispora cf. gigantea, Potonieisporites novicus, Potonieisporites cf. bhardwaji, Polymorphisporites laevigatus, Spinosporites spinosus, Calamos- pora sp., Cheileidonites sp., Cordaitina sp., Punctatosporites sp., 


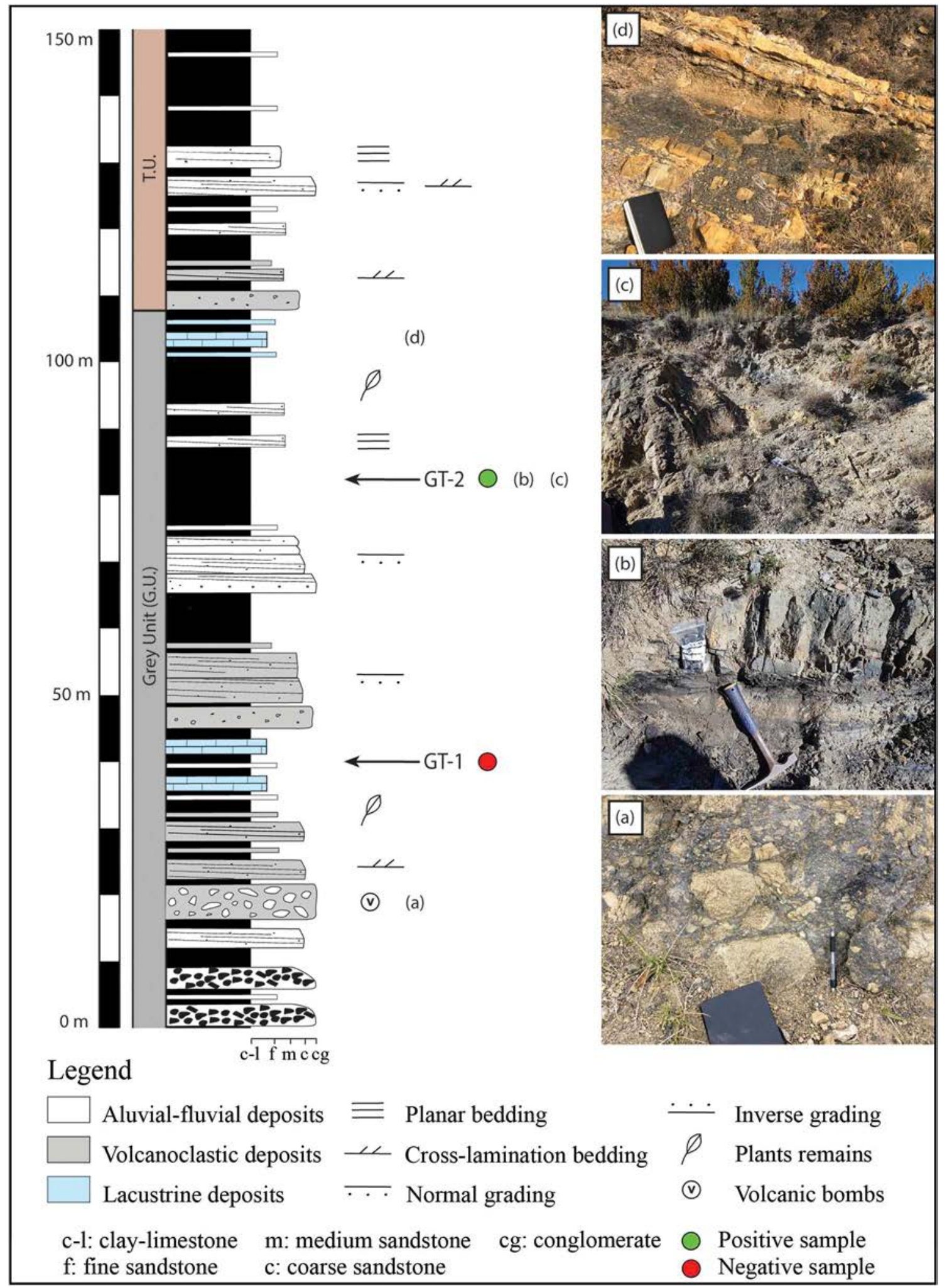

Fig. 4. Stratigraphic log of Gotarta section placed in Erill Castell Basin (Fig. 1A). A: Volcanic bombs are corresponding to the basal volcaniclastic deposits. B: Lacustrine deposits where GT2 was collected. C: A general overview of the lacustrine-fluvial deposits with dark colouration. D: Topmost deposits of Gotarta section with intercalation of carbonate deposits and dark-fine deposits corresponding to lacustrine deposits. 
Schopfipollenites sp. and indeterminate bissacates. These authors pro- posed a "lower Autunian age" based on its comparison with other studies in Western Europe (Remy and Remy, 1968; Doubinger, 1971, 1974; Bouroz and Doubinger, 1974; Coquel et al., 1976; Doubinger and Elsass, 1979). This association is very similar to the results described in 
this study for the Grey Unit assemblage because of the presence of the genera Calamospora, Deltoidospora, Puntatosporites, Granulatisporites, Lundbladispora and the monosaccate pollen.

The samples from the Grey Unit described in the present work show spores and pollen that are frequent in "Stephanian" associations 

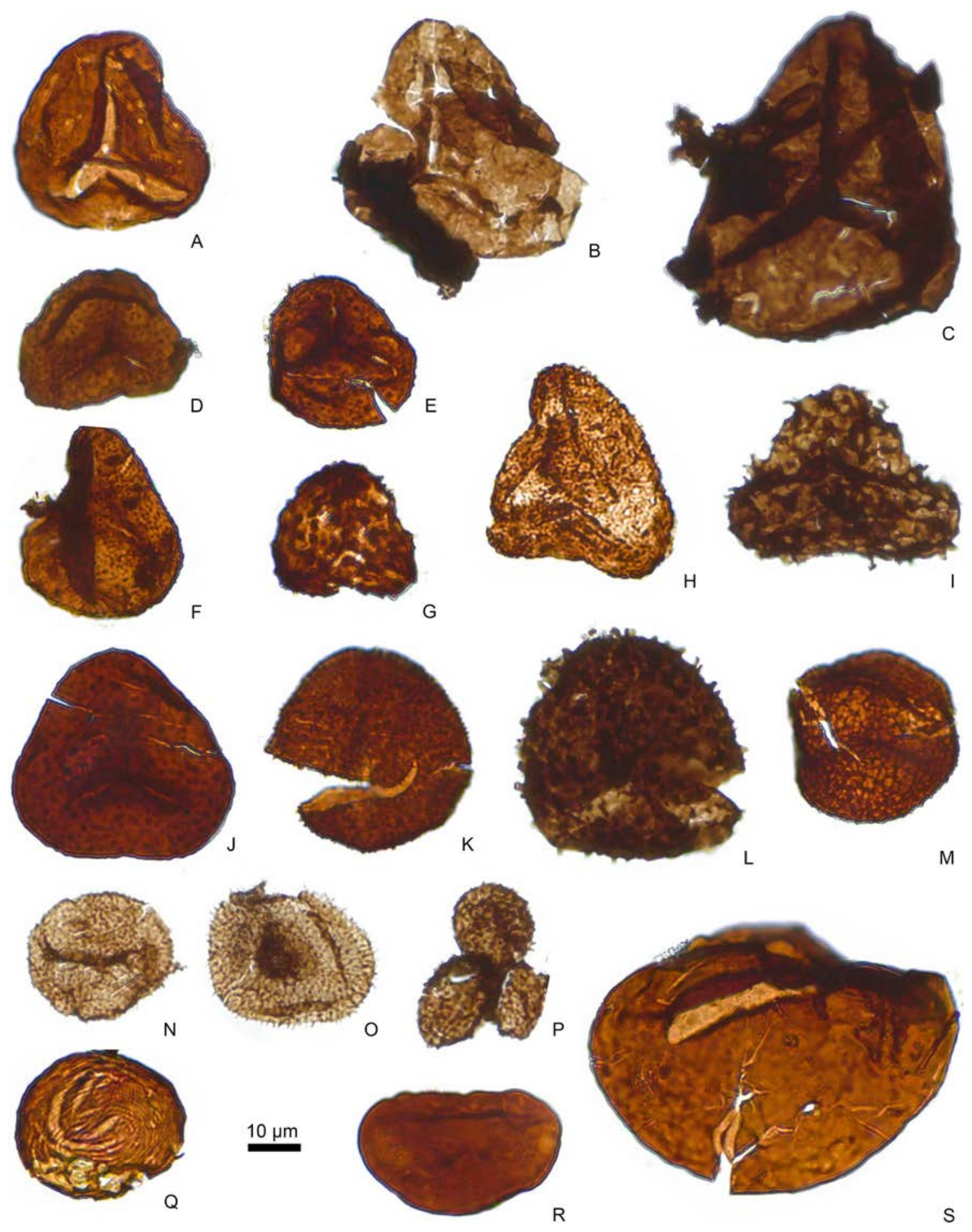

Fig. 5. GU palynological assemblage. A: Deltoidospora priddyi. B: Deltoidospora adnata. C: Deltoidospora sphaerotriangula. D: Granulatisporites minutus. E: Granulatisporites granulatus. F: Granulatisporites microgranifer. G: Lophotriletes microsaetosus. H: Acanthotriletes tenuispinosus. I: Acanthotriletes echinatus. J: Cyclogranisporites microgranus. K: Apiculatisporis parvispinosus. L: Apiculatisporis microacanthus. M: Maculatasporites sp. N: Punctatosporites punctatus. O: Spinosporites sp. P: Punctatosporites minutus. Q: Chromotriletes sp. R: Laevigatosporites perminutus. S: Laevigatosporites vulgaris. 
tenuispinosus, Angulisporites splendidus, Apiculatisporis microacanthus, Apiculatisporis parvispinosus, Cirratriradites rarus, Cyclogranisporites microgranus, Deltoidospora adnata, Deltoidospora priddyi, Deltoidospora sphaerotriangula, Granulatisporites granulatus, Granulatisporites microgranifer, Granulatisporites minutus, Laevigatosporites perminutus, Laevigatosporites vulgaris, Latensina trileta, 
Lophotriletes microsaetosus, Lundbladispora gigantea, Punctatosporites minutus, Punctatosporites punctatus, Florinites junior, Florinites mediapu-dens and Savitrisporites camptotus. The presence of "Autunian micro- flora" (represented in the Grey Unit by monosaccate pollen) such as Guthoerlisporites sp., Nuskoisporites sp., Plicatipollenites sp., Potonieisporites simplex and, particularly, Potonieisporites novicus would indicate a younger age for these materials. 

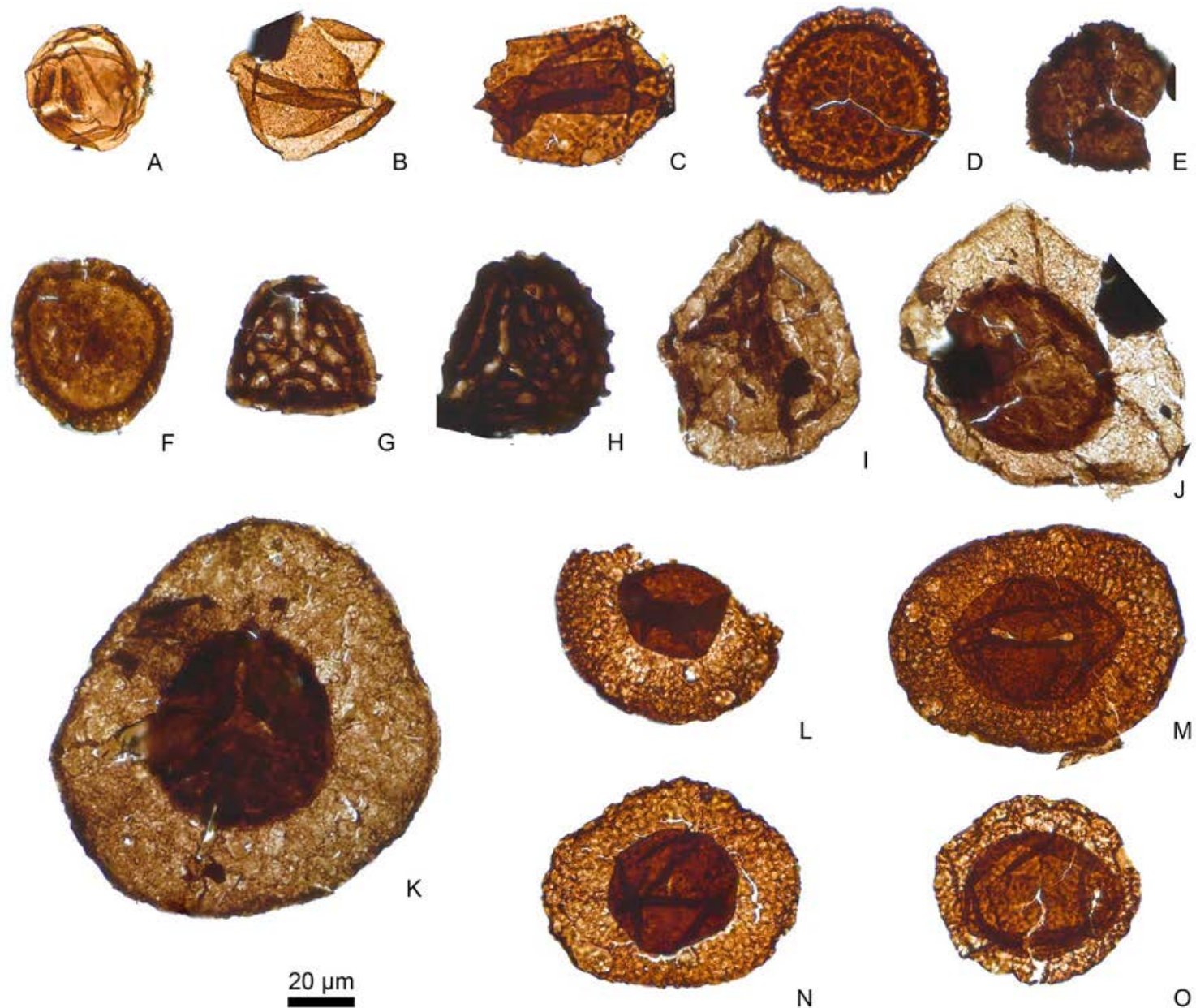

$\mathrm{N}$
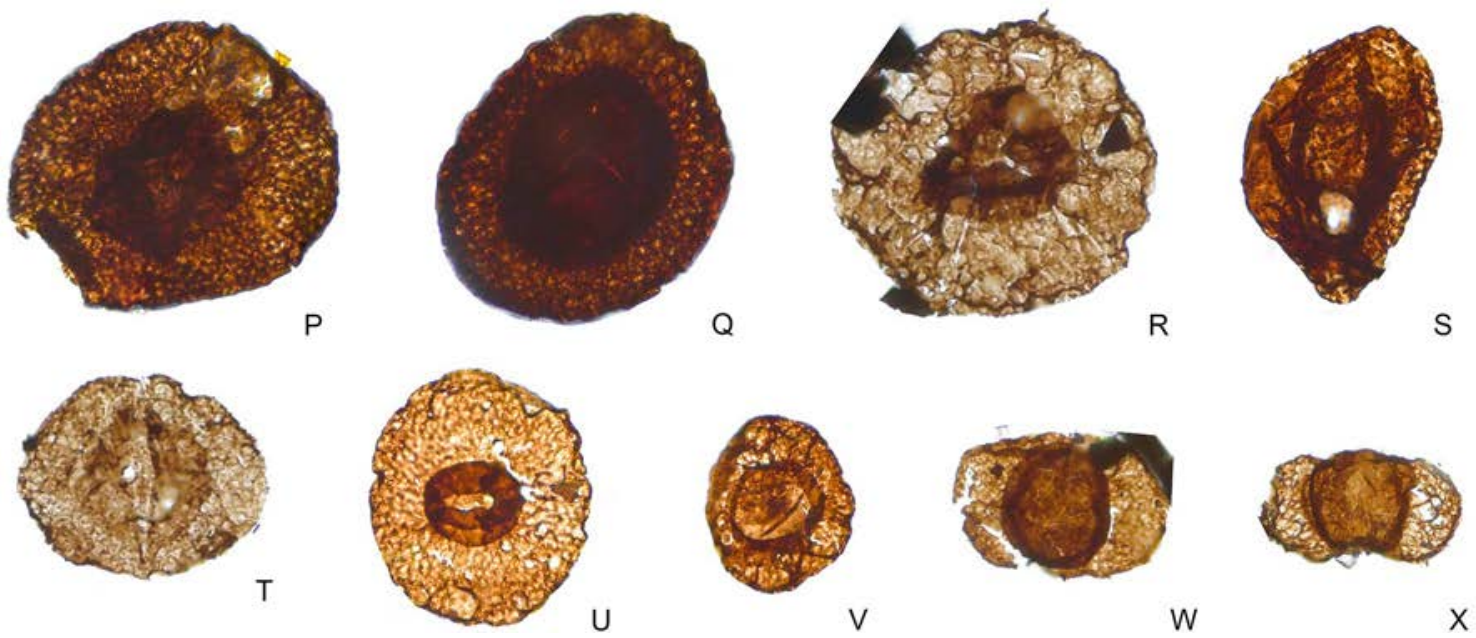

Fig. 6. GU palynological assemblage. A: Calamospora breviradiata. B: Calamospora microrugosa. C: Calamospora pedata. D: Lundbladispora gigantea. E: Lundbladispora sp. F: Latensina trileta. G: Dictyotriletes sp. H: Savitrisporites camptotus. I: Angulisporites splendidus. J: Cirratriradites rarus. K: Endosporites sp. L: Potonieisporites simplex. M: Potonieisporites sp. N: Potonieisporites novicus. O: Plicatipollenites sp. P: Guthoerlisporites sp. Q: Nuskoisporites sp. R: Wilsonites sp. S: Vestispora cf. cancellata. T: Vesicaspora wilsonii. U: Florinites junior. V: Florinites mediapudens. W-X: Unidentified Disaccites. 
Although the presence of mixed microflora has been reported even in the Permian, the appearance of Angulisporites splendidus, Latensina trileta, Lundbladispora gigantea, Savitrisporites camptotus, Vestispora cf. cancellata and Dictyotriletes sp. would indicate an older age (pre- Asselian age). Laevitagosporites spp. is also more common in the Carboniferous age (Clayton et al., 1977). 
To understand the "mixed flora" concept and its attendant pro- blems, we need to observe the first appearance of the taxa that will become dominant during the Permian. Therefore, the presence and diversification of monosaccate pollen (e.g. genus Potonieisporites) is 


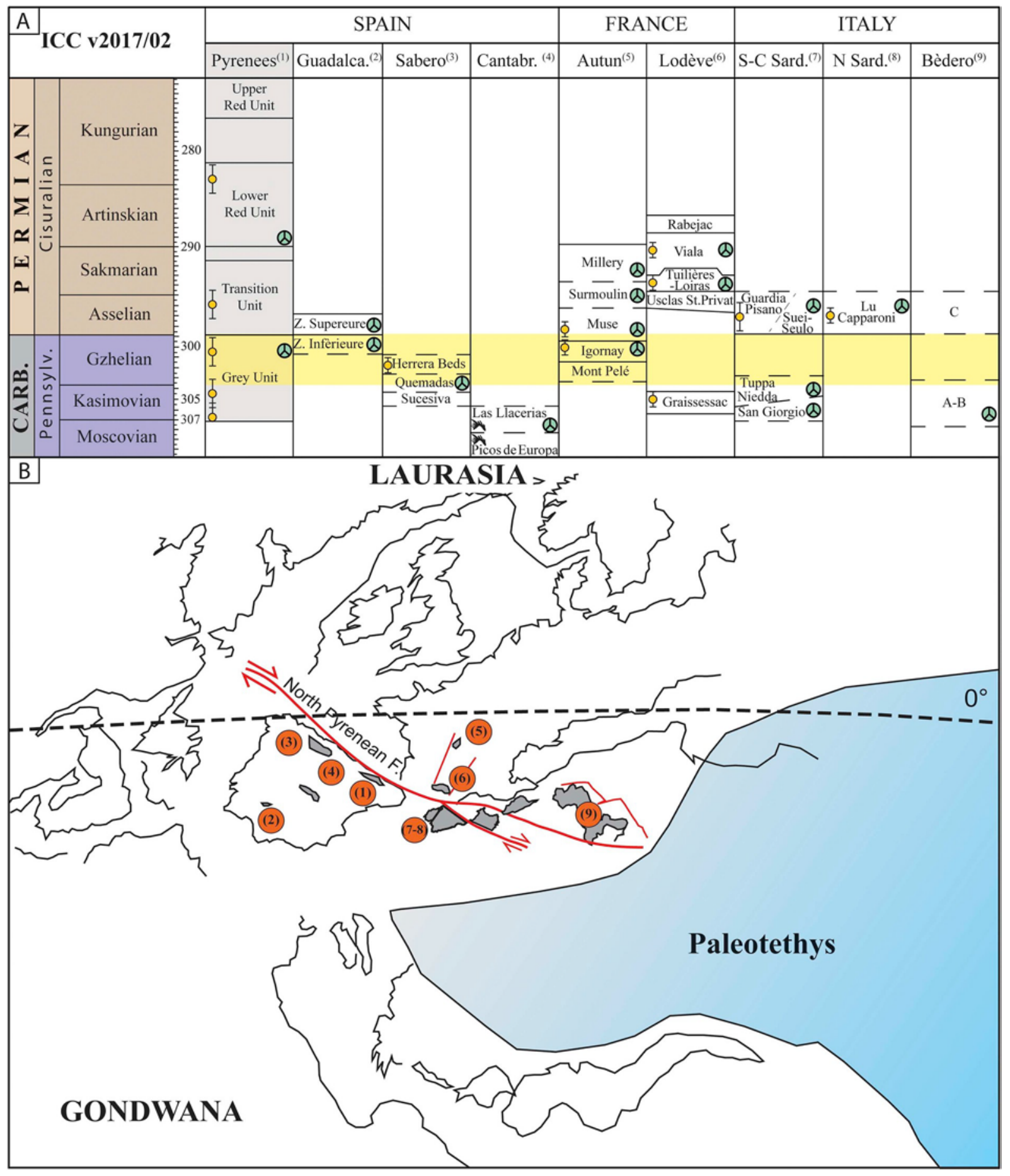

Fig. 7. A: Chronostratigraphic table of the Late Carboniferous-lower Permian basins in southwestern Europe with comparable palynological assemblages. (1) Absolute ages from Pereira et al. (2014). Palynology: This work and Broutin and Gisbert (1985). (2) Palynology from Broutin (1986) (3) Absolute age from Knight and Wagner (2014). Palynology from Juncal et al., work in progress (4) Palynology from Coquel and Rodriguez (1994) (5) Absolute ages from Pellenard et al. (2017). Palynology from Doubinger (1974) (6) Absolute ages from Michel et al. (2015). Palynology from Doubinger (1974). (7) Absolutes age from Pittau et al. (2002) and Gaggero et al. (2017). Palynology from Pittau and Del Rio (2002, 2004), Pittau et al. (2002, 2008a, 2008b). (8) Absolute age from Gaggero et al. (2017). Palynology from Broutin et al. (1999). (9) Palynology from Pittau et al. (2008a, 2008b). B: Paleogeographical map of the 
western Paleotethys with the location of the reviewed palynological assemblages.

fundamental to analyse Upper Carboniferous-early Permian rocks.

The first appearance of the genus Potonieisporites (typical "Autunian taxa") in the Late Carboniferous sediments was reported for the upper Westphalian (upper Moscovian) - Barruelian (lower Kasimovian) in- terval (Clayton et al., 1977). 
In Western Europe, it has been reported in the Cantabrian Zone (North of Spain; Fig. 7A) from the Picos de Europa and Puentellés (Las Llacerias) Formations. The palynological study was carried out in this region by Coquel and Rodriguez (1994) indicates a stratigraphic in- terval corresponding to the upper part of Asturian to Barruelian. A comparison with the data of Clayton et al. (1977) is difficult because the palynomorphs were found in a marine section. However, the mi- crofloral assemblages point to the Thymospora obscura-Thymospora thiessenii Zone (Asturian Barruelian) due to the presence of the genera Microreticulatisporites, Polymorphisporites and Raistrickia and the taxa Cirratriradites saturni, Crassispora kosankei, Radiizonates tenuis, Savitrisporites camptotus and Westphalensisporites irregularis, together with the appearance of Thymospora spp., Potonieisporites spp. and Angulis- porites splendidus (Fig. 8). The Upper Carboniferous hygrophytic mi- croflora is also present. This temporal attribution is consistent with the age provided by conodonts (Blanco-Ferrera et al., 2004; Mendez, 2006; Buggisch et al., 2008) that located the upper Moscovian-Kasimovian succession in the Las Llacerias Section (García-López and Sanz-López, 2002a, 2002b; Buggisch et al., 2008). 


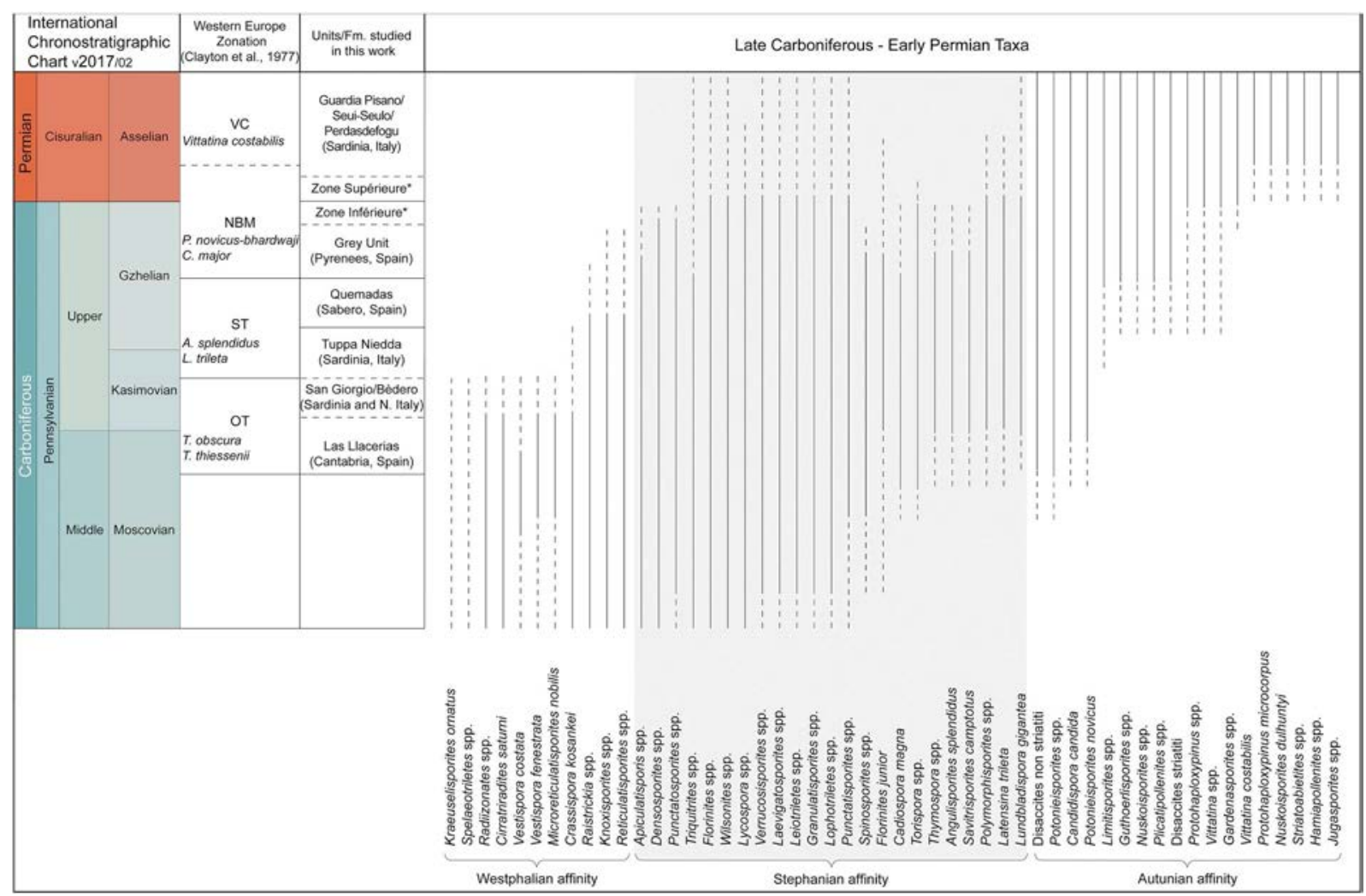

Fig. 8. Palynological Biozones of Late Carboniferous-early Permian taxa observed in this study (modified from Clayton et al., 1977. Adjusted to the latest research results). The microflora is separated by its "Westphalian", "Stephanian" and "Autunian" affinity. The "Zone Supérieure" and "Zone Inférieure" are located in Guadalcanal, Spain.

In slightly younger materials, a proliferation of this typical "Autunian" monosaccate pollen has been observed. Pittau et al. (2008b) reported miospore assemblages in Bèdero (west part of the Southern Alps, North of Italy. Fig. 7A). These authors suggest a Thymospora ob- scura-Thymospora thiessenii Zone of Western Europe for these deposits due to the presence of a large amount of Potonieisporites (with diverse species) and a group of taxa representative of the Westphalian paly- noflora of Western Europe, such as the genera Raistrickia, Spelaeotriletes, Stenozonotriletes, Endosporites and the "Stephanian" taxa Crassispora kosankei, Savitrisporites camptotus and Thymospora thiessenii (Clayton et al., 1977)(Fig. 8). Furthermore, Pittau et al. (2008b) compare the Bèdero assemblage with the one from the Saar Lorrain Basin, a locality typical of the Asturian strata (Alpern, 1963; Alpern and Liabeuf, 1966; Alpern et al., 1969), with the miospore assemblages of the San Giorgio basin (Southwest of Sardinia, Italy. Fig. 7A, recently dated by macro- flora as late Asturian age, late Moscovian by Cleal et al., 2017) and the Late Carboniferous and early Permian microflora from Southwest of Sardinia (Pittau and Del Rio, 2002, 2004; Pittau et al., 2002, 2008b).

These latest Carboniferous assemblages from Southwest Sardinia are related to the San Giorgio Basin and the Tuppa Niedda section (Southwest of Sardinia, Italy. Fig. 7A) and their chronostratigraphic assignation probably encompasses the Bolsovian to the Barruelian ("Pteridophytic, pre-Striatiti" Palynological Phase. Del Rio and Pittau, 2004; Pittau and Del Rio, 2004). This hypothesis is based on the broad palynological similarities between these assemblages and those of many other European sections (Clayton et al., 1977). These palynofloras are considered to be characteristic of the late Westphalian-early Stephanian ages because they contain a diversity of pteridophytic, sphenophytic, lycophytic and pteridospermaphytic spores and cordaite pollen. In the San Giorgio Basin (Pittau et al., 2008a), the presence of the genera Spelaeotriletes and Kraeuselisporites, with possible Kraeuselisporites or- natus, previously recorded from the Namurian-Westphalian interval in 
Western Europe and extending up to the Westphalian-Stephanian(?) in Saudi Arabia (Owens and Turner, 1995) is coherent with their sug- gestion (Fig. 8). In the Tuppa Niedda assemblage (Pittau et al., 2008a), gymnosperm pollen are mainly represented by Florinites species, whereas Potonieisporites is very rare. The assemblage includes a large component of representative Late Carboniferous genera, such as Leio-triletes (= Deltoidospora),

Cyclogranisporites, Cadiospora, Lophotriletes, Convolutispora, Microreticulatisporites,

Reticulatisporites and Triquitrites, which would show a "Stephanian B affinity" for this section (Fig. 8).

It is during the Stephanian age that hygrophilous flora became dominant. The typical Upper Carboniferous ferns of the tedeleacean, zygoptetidaceae, gleicheniaceae and boctryopteridaceae groups (such as Deltoidospora, Lophotriletes, Punctatisporites, Spinosisporites, Triquitrites and Verrucosisporites), the marattialean ferns (such as Thymospora or Punctatosporites) and lycopsids (as Lycospora, Lundbladispora and Crassispora) are present here. The diversification of cordaite pollen (such as Florinites and Latensina) is also characteristic of this period (Fig. 8). The presence of Potonieisporites is rare, even though it fre- quently occurs during such period of time. This proposition is coherent with the microflora found recently in the Saberian stratotype 
(Quemadas Formation. Juncal et al., work in progress) located in the Sabero Coalfield (León, Spain). The Saberian microflora corresponds to the Angulisporites splendidus-Latensina trileta (ST) Zone (Clayton et al., 1977), due to the abundance of Lycospora pusilla, Densosporites spp., Laevigatosporites spp., Thymospora sp., Florinites spp., and the presence of more or less constant numbers of Disaccites non striatiti, Angulis- porites splendidus, Latensina trileta, Spinosporites spinosus, Candidispora sp. and Lundbladispora sp. Furthermore, the Barruelian-Stephanian B boundary was recognised in the Sabero Coalfield (NW Spain) in cor- relation with the putative Stephanian A (Barruelian)-B boundary identified in the Carmaux Coalfield (south-central of France. Knight and Wagner, 2014). The preliminary age determinations indicate that the lower part of the Saberian corresponds to an age of $302.25 \pm 0.28 \mathrm{Ma}$ and $302.13 \pm 0.23 \mathrm{Ma}$ (Knight and Wagner, 2014).

\subsection{The problematic issue of "Stephanian-Autunian mixed flora"}

The diversification of the "Autunian microflora" has not been ob- served until the latest Carboniferous. A great variety of monosaccate pollen of the genera Cordaitina, Guthoerlisporites, Nuskoisporites Plicatipollenites and Potonieisporites have been observed, together with the "Stephanian microflora". Broutin (1986) distinguishes two paly- nological zones for these levels.

1) The "Zone inférieure" in which the trilete spores are the most abundant. In Guadalcanal (Southwest of Spain, Broutin, 1986), it is characterized by the dominance of Crassispora plicata and the ab- sence of the genera Thymospora and Lycospora (that were presented as relics in some of the studied levels). Also, the absence of the genera Punctatosporites and Densosporites, linked to the Upper Car- boniferous, was observed (Fig. 8). For these reasons, Broutin (1986) suggests a "terminal" Stephanian age for these associations. We also compared the "Zone Inférieure" with the classic baseline study of Doubinger (1974), which described the palynological studies of the "Autunian flora" of the French Basins of Autun, Blanzy, l'Aumance, Brive and Lodève (Fig. 7A). Doubinger (1974) distinguishes three associations (A1 to A3). The "Zone A1" is the one that fits best with the Guadalcanal assemblages. The "mixed flora" of "Zone A1" ("lower Autunian age") is characterized by a decrease in the genera Thymospora and Punctatosporites, which are replaced by smooth monolete spores of the genus Laevigatosporites. the Moskovian pa- lynomorphs reported in the Cantabrian Zone, Bédero and San Giorgio (such as Crassispora kosankei, Cirratritadites saturni, Radii- zonates tenuis, Savitrisporites camptotus, Kraeuselisporites spp., Spe- laeotriletes spp. and Stoenozonotriletes spp.) are no longer present, being replaced by monosaccate pollen of the genera Florinites, Po- tonieisporites, Guthoerlisporites, Candidispora and Wilsonites. This mi- croflora is characteristic of Assise d'Igornay (Doubinger, 1974), re- cently dated as late Gzhelian $(299.91 \pm 0.38 \mathrm{Ma}$ ) by Pellenard et al. (2017).

2) The "Zone Supérieure" of Broutin (1986) is typically characterized by the very strong dominance of monosaccate pollen. Using a quantitative method and considering the local variation of the composition, this association is quite comparable with "Zone A2" of Doubinger (1974). The "Autunian microflora" of "Zone A2" displays a very scarce presence of "Stephanian elements" (such as the genera Lundbladispora, Triquitites and Verrucosisporites, while the genus Thymospora is relict). The genus Potonieisporites displaces the Flor- inites and Wilsonites genera, and the striated disaccites, monocolpate pollen and striated forms from the genus Vittatina are always pre- sent. This microflora is characteristic of Assise de Muse (Doubinger, 1974), recently dated as Asselian age (298.57 $\pm 0.38-298.05 \pm$

$0.39 \mathrm{Ma}$ ) by Pellenard et al. (2017), and the Tuilière and Usclas, Saint-Privat, from the Lodève Basin (Doubinger, 1974), dated as Sakmarian age (Tuilière -Loiras Fm., 293.85 $\pm 0.10 \mathrm{Ma}$. Michel et al., 2015). 
The differentiation between the Upper Carboniferous and lower Permian deposits is not obvious when interspersed levels of coal layers (or levels with a higher concentration of organic matter) in Permian deposits appear with a palynological assemblage similar to that of "Stephanian microflora" (e.g. Broutin, 1986; Paquette et al., 1980).

Focusing on this problem, Broutin (1986) proposed a systematic examination that analyzed and compared the microflora of these strata with genuine "Stephanian assemblages". When "Autunian flora" ap- pears between Stephanian materials (e.g. Doubinger et al., 1979), the immediately subsequent "Stephanian assemblage" occurs without any impoverishment in its composition. In contrast, when "Stephanian flora" appears within lower Permian sediments (e.g. Guadalcanal sec- tion, Southwest of Spain, described by Broutin, 1986), the genera Thymospora, Punctatosporites or Densosporites are never observed, probably because they could not survive the first manifestations of climate change, instability and gradual evolution to drier conditions (Broutin, 1986).

Finally, in clearly early Permian sediments, the assemblages contain mainly Potonieisporites, striated taxa and other walchian conifer pollen. Following the recommendations of Broutin (1986), we study the as- semblages of Pittau et al. (2002, 2008b) from Guardia Pisano basin (southwest of Sardinia. Fig. 7A) in which Potonieisporites spp. is domi- nant (35-57\%), the taeniate and ataeniate disaccate pollen correspond to the $20-25 \%$ of the assemblage and the spores are generally very rare (2\%) (Pittau et al., 2008b). It is observed the presence of Late Carbo- niferous microflora as Densosporites sp., Granulatisporites sp., Knox-isporites glomus, Lavigatosporites vulgaris, Lophotriletes sp., Lycospora pu- silla, Punctatosporites minutus, Raistrickia sp., Spelaeotriletes sp., Thymospora sp. and Triquitrites spp., together with Permian taxa Costapollenites ellipticus, Hamiapollenites bullaeformis, Limitisporites sp., Vit- tatina sp. and an aptypical presence of genera Crucisaccites and Lueck-isporites (Pittau et al., 2002). The description of these assemblages is comparable with the "Zone inferieure" of Broutin (1986) with domi- nant taxa (Potonieisporites spp.) and some spores presented as relics (Densosporites, Puntatosporites and Thymospora). The assignation of these assemblages to the late Gzhelian is consistent with the absolute dating age obtained in the interlayered volcanic rocks, breccia and lava flow at the base of Guardia Pisano basin (297 $\pm 5 \mathrm{Ma}$, Pittau et al., 2002). Also, in the Seui Seulo lacustrine deposits equivalent to the Guardia Pisano Fm. (Seui Seulo Fm., central-eastern Sardinia. Fig. 7A) was assigned to the "Potonieisporites Phase", of early Asselian age by Pittau et al. (2008b). At the top of Seui-Seulo Basin, Gaggero et al. (2017) obtained in rhyolitic ignimbrites a $294 \pm$ 3.0 $\mathrm{Ma}$ and $296 \pm$ 4.3 Ma ages. A similar age (295 $\pm 3.5 \mathrm{Ma}$, Gaggero et al., 2017) is registered in the dacites capping the Rio su Luda Fm. (Per- dasdefogu Basin, central-eastern Sardinia). The macroflora remains obtained in this formation was compared by Broutin et al. (1999) with the Assise de Millery (“Upper Autunian”, Autun Basin, France. Fig. 7A). In Punta Lu Caparoni (Nurra Basin, north of Sardinia, Fig. 7A), a pa- lynological assemblage is reported in Broutin et al. (1999). The as- semblage contains a dominance of Potonieisporites novicus and Potonieisporites bhardwajii (50\% of the assemblage) and the taxa Costapollenites sp., Florinites spp., Hamiapollenites cf. bullaeformis, Illinites spp., Laevigatosporites spp., Limitisporites spp., Lundbladispora cf. gi- gantea, Nuskoisporites cf. dulhuntyi, Playfordiaspora crenulata, Protohaploxypinus samoilovichii, Striatoabieites sp., Vittatina ovalis and Vitta- tina sp. The macroflora of Punta Lu Caparoni is also attributed to "Upper Autunian" age by comparison with the Assise de Millery (Broutin et al., 1999) although recent zircon dating indicates $297 \pm 1.8 \mathrm{Ma}$ to the Punta Lu Caparoni ignimbrite (Gaggero et al., 2017).

\subsection{The age of Grey Unit microflora}

In the "Stephanian microfl the appearance of distinctive ele- ments is key to characterize the Late Carboniferous assemblages. Thepresence of some Westphalian elements (e.g. Cirratriradites, 
Kraeuselisporites, Radiizonates and Spelaeotriletes) would indicate that the sediments are older than strata of other areas with typical Stephanian taxa, such as Angulisporites splendidus, Latensina trileta, Lundbladispora gigantea and Savitrisporites camptotus. The proliferation of monosaccate pollen (genera Florinites, Potonieisporites, Guthoerlisporites, Candidispora and Wilsonites) suggests a "terminal" Carboniferous age. On the other hand, the presence of striated taxa (such as Vittatina, Hamiapollenites and Protohaploxypinus) and bisaccate palynomorphs (e.g. Jugasporites and Gardenasporites) would indicate a Permian age (Fig. 8).

The Grey Unit shows the presence of "Stephanian microflora" and the diversification of monosaccate pollen such as Guthoerlisporites sp., Nuskoisporites sp., Plicatipollenites sp., Potonieisporites simplex and Potonieisporites novicus. The presence of Upper Carboniferous elements, such as Angulisporites splendidus, Latensina trileta, Lundbladispora gi- gantea, Savitrisporites camptotus and Dictyotriletes sp. (with Stephanian affinity, Fig. 8), in the studied samples, suggests a Gzhelian age. Moreover, the Grey Unit microfloral assemblage is comparable with the "Zone inférieure" of Broutin (1986), which is equivalent to the micro- flora of Assise d'Igornay (Doubinger, 1974) dated as late Gzhelian (299.91 $\pm 0.38 \mathrm{Ma}$, Pellenard et al., 2017).

This age also fits very well with the absolute radiometric ages provided by Pereira et al. (2014), obtained from volcanic rocks inter- bedded in the Grey Unit deposits in the two neighbouring areas of Coll de Vanses (304.6 $\pm 1.5 \mathrm{Ma}$, Fig. 1B) and the Cadí Ignimbrite (300.4 \pm 1.4 Ma, Fig. 1B).

Once the age of the Grey Unit is established, a palynological com- parison with the Western Europe palynological Zonation of Clayton et al. (1977) is necessary. The Potonieisporites novicusbhardwaji - Cheiledonites major (NBM) Zone corresponds to the Assise d'Avaize, the Loire Basin and the Assise d'Igornay (Autun Basin), and is equivalent to the Stephanian C-D (Clayton et al., 1977).

The NBM Zone is characterized by the frequency of Cheiledonites spp., Potonieisporites spp., Spinosporites spinosus and the "top of the epibole" of Densosporites spp., and Savitrisporites camptotus. Also, in the NBM Zone there is an abundance of the genera Lycospora, Laevigatosporites, Punctatosporites, Thymospora, Spinosporites and Florinites, but also contains Autunian palynomorphs as Vittatina spp. and the disaccites striatiti (Clayton et al., 1977).

The presence of Angulisporites splendidus, Florinites spp., Laevigatosporites spp., Latensina trileta, Lundbladispora gigantea, Potonieisporites spp. Puntatosporites spp., Spinosporites spinosus, and the "disaccites non striatiti" are common on both assemblages.

Although both assemblages have similar age, the Grey Unit assem- blage has a hygrophytic affinity due to the presence of Acanthotriletes, Apiculatisporis, Deltoidospora, Granulatisporites, Lophotriletes and Punctatosporites. The outcrops used to define the NBM Zone are char- acterized by a drier environment with conditions more favourable for the appearance of xerophytic elements such as Vittatina and disaccites striatiti.

For the first time in the studied area, it is possible to calibrate a palynological assemblage with absolute ages (Fig. 7A) and thus corre- late the beginning of the Post-Variscan continental succession in the western Palaeotethys domain (Fig. 7B). These new palynological data indicate that the Southern Pyrenean basins started their development during the Kasimovian, as in the case of the Lodève basin (Fig. 7A), and continued during the Gzhelian. The Autun basin contains a Gzhelian palynomorph assemblage, but Gzhelian deposits have not been reported in the Lodève basin. This finding indicates significant sedimentary disconnections between neighbouring basins. The Italian basins seem to have begun their deposition before the French and Pyrenean ones, even though the most Upper Carboniferous was not recorded in the east- ernmost basins (Fig. 7B).

This disconnection between neighbouring basins could be re- sponsible for the differences between the Grey Unit assemblage and the NBM Zone of Clayton et al. (1977). The isolated basins of the Pyreneesacted as a refuge with more favourable conditions for the Carboniferous hygrophilous flora, delaying the appearance of the meso-xerophytic floras. 


\section{Conclusions}

We present the first palynological characterization of the Grey Unit in the Central-Eastern Pyrenees, Northeast Spain. Our palynological data were obtained from levels of the Gzhelian Grey Unit, radio- metrically dated as $304.6 \pm 1.5-300.4 \pm 1.4 \mathrm{Ma}$. The palynological assemblage obtained from the Grey Unit can be compared with the Assise d'Igornay one, which shows a zircon age of $299.91 \pm 0.38 \mathrm{Ma}$. For the first time, a palynological assemblage has been correlated with absolute ages in the Southern Pyrenees area, providing key in- formation on the chronostratigraphy of the Permo-Carboniferous tran- sition in southern Europe. Based on these results, it is possible to verify the validity of the classical Carboniferous

Palynological Zonation of Western Europe and the palynological studies of the "Autunian flora" of

the French Basins of Autun, Blanzy, l'Aumance, Brive and Lodève pre- sented in Doubinger (1974). Based on the comparison of our results with previous works, the microflora evolution in the Upper Carboni- ferous has been described at the low latitudes of the Euramerican Province. Furthermore, a comparison between these assemblages with different dating methods is presented to provide a solid base for sta- bilizing relationships between flora assemblages and palynostrati- graphic schemes in the Euroamerica province and other areas across Pangea.

The Grey Unit Assemblage is Gzhelian in age, as determined by U-Pb dating. This fact is also important for correlating the Post-Variscan continental basins in the Southwestern Palaeotethys, as well as their palaeogeography. The results presented in this study are indicative of a complex and diachronous evolution of these basins during the Late Carboniferous-early Permian. However, the sedimentary filling of the Southern Pyrenean basins and the French Autun basin started probably during the Gzhelian.

\section{Acknowledgements}

The authors are grateful to Dr. Cortland Eble and an anonymous reviewer for helpful and constructive suggestions and to the editor Dr. Isabel Montañez for her valuable recommendations. This research was supported by the CGL2014-52699P (Spanish Ministry) and GRC 2015/ 020 projects (Xunta de Galicia). Joan Lloret received financial support from the PhD research program of the University of Pavia (Italy).

\section{References}

Alpern, B., 1963. Coupe palynologique du Westphalien du Bassin Houiller de Lorraine. C. R. Acad. Bulg. Sci. Paris 256, 5170-5172.

Alpern, B., Liabeuf, J.J., 1966. Zonation palynologique du Bassin Houiller Lorrain. Z. Dtsch.

Geol. Ges. 117, 117-162.

Alpern, B., Choffé, M., Lachkar, G., Liabeuf, J.J., 1969. Synthèse des zonations palynologiques des bassins houillers de Lorraine et de Sarre. Rev. Micropaleontol. 11, 217221.

Álvarez-Ramis, C., 1985. Sobre la presencia de flora autuniense en las series carboníferas del Pirineo leridano (España). In: Compte Rendu 10e Congrès International de

Stratigraphie et Géologie du Carbonifère, Madrid 1983, 2. pp. 181-189.

Álvarez-Ramis, C., Doubinger, J., 1987. Microflora de Estac (Lerida). Cuad. Geol. Iber. 11, 131-137.

Álvarez-Ramis, C., Pi-Radondy, M., Doubinger, J., 1969. Sur la flore fossile du Carbonifère de Surroca (Gerona, Espagne). C. R. Acad. Sci. Paris 268, 2559-2561.

Álvarez-Ramis, C., Doubinger, J., Diéguez Jiménez, M.C., 1971. Estudio paleobotánico de la 
flora de Ogassa (Gerona). Estud. Geol. XXVII (3), 267-277.

Beerling, D.J., Lake, J.A., Berner, L., Hickey, J.D., Taylor, W., Royer, D.L., 2002. Carbon isotope evidence implying high $\mathrm{O} 2 / \mathrm{CO} 2$ ratios in the Permo-Carboniferous atmosphere. Geochim. Cosmochim. Acta 66 (21), 3757-3767.

Berner, R.A., Vandenbrooks, J.M., Ward, P.D., 2007. Oxygen and evolution. Science 316, 557-558.

Berthelin, M., Broutin, J., Kerp, H., Crasquin-Soleau, S., Platel, J.P., Roger, J., 2003. The Oman Gharif mixed paleoflora: a useful tool for testing Permian Pangea reconstruc- tions. Palaeogeogr. Palaeoclimatol. Palaeoecol. 196, 85-98.

Berthelin, M., Stolle, E., Kerp, H., Broutin, J., 2006. Glossopteris anatolica Archangelsky 
and Wagner 1983, in a mixed middle Permian flora from the Sultanate of Oman: comments on the geographical and stratigraphical distribution. Rev. Palaeobot. Palynol. 141, 313-317.

Bixel, F., Lucas, C., 1983. Magmatisme, tectonique et sédimentation dans les fossés stéphano-permiens des Pyrénées occidentals. Rev. Géogr. Phys. Géol. Dyn. 24, 329_ 342.

Blake, B.M., Cross, A.T., Eble, C.F., Gillespie, W.H., Pfefferkorn, H.W., 2002. Selected plant megafossils from the Carboniferous of the Appalachian region, United States. In: Hills, L.V., Henderson, C.M., Bamber, E.W. (Eds.), Carboniferous and Permian of the World. vol. 19. pp. 259-335 Canadian Society of Petroleum Geologists, Memoir.

Blanco-Ferrera, S., Garcia-López, S., Sanz-López, J., 2004. Conodontos carboníferos de la sección el río Cares (Unidad de Picos de Europa, Zona Cantábrica, NO de España). Geobios 38, 17-27.

Bouroz, A., Doubinger, J., 1974. Les relations entre le Stéphanien supérieur et l'Autunien d'après le contenu de leur stratotype. C. R. Acad. Sci. Paris 279, 1745-1748.

Bouroz, A., Doubinger, J., 1977. Report on the Stephanian-Autunian boundary and on the contents of Upper Stephanian and Autunian in their stratotypes. In: Holub, V.M., Wagner, R.H. (Eds.), Symposium on Carboniferous Stratigraphy. Geological Survey, Prague, pp. 147-169.

Broutin, J., 1986. Étude paléobotanique et palynologique du passage Carbonifère Permien dans le sud-ouest de la Péninsule Ibérique: Cahiers de Paléontologie, Éditions du Centre National de la Recherche. Scientifique, Paris (165 pp).

Broutin, J., Berthelin, M., 2005. Dynamic of settlement of mixed floras during the Permian in the Peri-Tethyan domain: paleogeographic and paleoclimatic significance. In: Lucas, S.G., Zeigler, K.E. (Eds.), The Nonmarine Permian. New Mexico Museum of Natural History and Science Bulletin, vol. 30. pp. 24-25.

Broutin, J., Gisbert, J., 1985. Entorno paleoclimático y ambiental de la flora stephanoautuniense del Pirineo catalán. In: Compte rendus Dixième International de Stratigraphie et de Géologie du Carbonifère, pp. 53-66.

Broutin, J., Doubinger, J., Langiaux, J., Primey, D., 1986. Conséquences de la coexistence de flores à caractères stéphaniens et autuniens dans les bassins limniques d'Europe occidentale. Soc. Géol. Fr. Mém. 149, 15-25.

Broutin, J., Doubinger, J., Farjanel, G., Freytet, P., Kerp, H., Langiaux, J., Lebreton, M.L., Sebban, S., Satta, S., 1990a. Le renouvellement des flores au passage CarbonifèrePermien: approche stratigraphique, biologique, sédimentologique. C. R. Acad. Sci. 311 (2), 1563-1569.

Broutin, J., Doubinger, J., El Hamet, M.O., Lang, J., 1990b. Palynologie comparée du Permien nigérien (Afrique occidentale) et Péritéthysien. Implications strati- graphiques et phytogéographiques. Rev. Palaeobot. Palynol. 66, 243-261.

Broutin, J., Cabanis, B., Châteauneuf, J., Beroin, J., 1994. Évolution biostratigraphique, magmatique et tectonique du domaine palététhysien occidental (SW de l'Europe): implications palégéographiques au Permien inférieur. Bull. Soc. Geol. Fr. 165, 163-179.

Broutin, J., Diez, J., Ronchi, A., 1999. The Lower Permian deposits of Punta lu Caparoni. Paleontologica data. In: Cassinis, G., Cortesogno, L., Gaggero, L., Pittau, P., Ronchi, A., Sarria, E. (Eds.), Late Palaeozoic Continental Basins of Sardinia. Field trip Guide- Book. International Field Conference on "The Continental Permian of the Southern Alps and Sardinia. Regional Report and General Correlations", 15-18 September 1999, Brescia, Italy. Earth Science Department, Pavia University, pp. 98-101.

Bruguier, O., Becq-Giraudon, J.F., Champenois, M., Deloule, E., Ludden, J., Mangin, D., 2003. Application of in situ geochronology and accessory phase chemistry to constraining basin development during post-collisional extension: a case study from the 
French Massif Central. Chem. Geol. 201, 319-336.

Buggisch, W., Joachimski, M.M., Sevastopulo, G., Morroz, J.R., 2008. Mississippian $\delta 13$ Ccarb and conodont apatite $\delta 180$ records - their relation to the Late Palaeozoic Glaciation. Palaeogeogr. Palaeoclimatol. Palaeoecol. 268, 273-292.

Cascales-Miñana, B., Cleal, C.J., 2014. The plant fossil record reflects just two great extinction events. Terra Nova 26, 195-200.

Cassinis, G., Di Stefano, P., Massari, F., Neri, C., Venturini, C., 2000. Permian of South Europe and its interregional correlation. In: Yin, H., Dickins, J.M., Shi, G.R., Tong, J. (Eds.), Developments in Palaeontology and Stratigraphy, Permian-Triassic Evolution of Tethys and Western Circum-Pacific. Elsevier, pp. 37-70.

Cassinis, G., Durand, M., Ronchi, A., 2003. Permian-Triassic continental sequences of Northwest Sardinia and South Provence: stratigraphic correlations and palaeogeographical implications. Boll. Soc. Geol. Ital. 119-129 (Volume speciale).

Cassinis, G., Perotti, C.R., Ronchi, A., 2012. Permian continental basins in the Southern Alps (Italy) and peri-mediterranean correlations. Int. J. Earth Sci. 101, 129-157.

Clayton, G., Coquel, R., Doubinger, J., Gueinn, K.J., Loboziak, S., Owens, B., Streel, M., 1977. Carboniferous miospores of Western Europe: illustration and zonation. Med. Rijks Geol. Dienst. 29, 1-71.

Cleal, C.J., 2016. A global review of Permian macrofloral biostratigraphical schemes. In: Lucas, S.G., Shen, S.Z. (Eds.), The Permian Timescale. London: Geological Society, Special Publications, vol. 450. pp. 1-15.

Cleal, C.J., Opluštil, S., Thomas, B.A., Tenchov, Y., 2010. Late Moscovian terrestrial biotas and palaeoenvironments of Variscan Euramerica. Neth. J. Geosci. 88, 181-278.

Cleal, C.J., Opluštil, S., Thomas, B.A., Tenchov, Y., 2011. Pennsylvanian vegetation and climate in tropical Variscan Euramerica. Episodes 34, 3-12.

Cleal, C.J., Scanu, G.G., Buosi, C., Pittau, P., Kustatscher, E., 2017. Middle Pennsylvanian vegetation of the San Giorgio Basin, southern Sardinia (Italy). Geol. Mag. 154 (5), 11551170.

Coquel, R., Rodriguez, R., 1994. Palynology of the Picos de Europa and Puentellés Formations in the Picos de Europa area (Upper Carboniferous, northwest Spain). Rev. Palaeobot. Palynol. 80, 65-74.

Coquel, R., Doubinger, J., Loboziak, S., 1976. Les microspores-guide du westphalien à l'Autunien d'Europe Occidentale. Rev. Micropaleontol. 18 (4), 200-212.

Dalloni, M., 1930. Étude géologique des Pyrénées catalanes. Ann. Fac. Sci. Marseille XXVI (3), 1-373.

Del Rio, M., Pittau, P., 2004. The Upper Carboniferous of the San Giorgio basin. In: 32nd International Geological Congress: Sardinia Palaeozoic Basement and Its Meso- Cenozoic Covers (Italy). pp. 39 (16-18). 
DiMichele, W.A., Aronson, R.B., 1992. The Pennsylvanian-Permian vegetational transi- tion: a terrestrial analogue of the onshore-offshore hypothesis. Evolution 46, 807-824.

DiMichele, W., Mamay, S., Chaney, D., Hook, R., Nelson, W., 2001a. An Early Permian flora with Late Permian and Mesozoic affinities from north-central Texas. J. Paleontol. 75 (2), 449-460.

DiMichele, W.A., Pfefferkorn, H.W., Gastaldo, R.A., 2001b. Response of late Carboniferous and early Permian plant communities to climate change. Annu. Rev. Earth Planet. Sci. 29, 461-487.

DiMichele, W.A., Tabor, N.J., Chaney, D.S., Nelson, W.J., 2006. From wetland to wet spots: environmental tracking and the fate of Carboniferous elements in Early Permian tropical floras. In: Greb, S.F., DiMichele, W.A. (Eds.), Wetlands Through Time. Geological Society of America, Special Papers Vol. 399. pp. 223-248.

DiMichele, W.A., Montañez, I.P., Poulsen, C.J., Tabor, N.J., 2009. Vegetation-climate feedbacks and regime shifts in the late Paleozoic ice age earth. Geobiology 7, 200-226.

Doubinger, J., 1971. Contribution a la palynologie de l'Autunien: Ies schistes de Charmoy, Bassin de Blanzy (Saône-s-Loire). Bull. Soc. Hist. Nat. Autun 58, 15-18.

Doubinger, J., 1974. Études palynologiques dans l'Autunian. Rev. Palaeobot. Palynol. 17, 21-38.

Doubinger, J., Álvarez-Ramis, C., 1984. Flores de quelques bassins stéphaniens d'Espagne: corrélations avec les flores du stratotype de Saint-Etienne (France). In: Compte Rendu 9e Congrès International de Stratigraphie et Géologie du Carbonifère, Washington and Champaign-Urbana 1979, 2. pp. 515-522.

Doubinger, J., Elsass, P., 1979. Le bassin Permo-Carbonifère d'Autun. Nouvelles données stratigrapbiques et palynologiques. Bull. Soc. Hist. Nat. Autun 91, 9-25.

Doubinger, J., Roy-Dias, C., 1985. La paléoflore du Stéphanien de l'Oued Zat (Haut Atlas de Marrakech-versant Nord - Maroc). Geobios 18, 573-586.

Doubinger, J., Robert, J.F., Broutin, J., 1978. Données complémentaires sur la flore Permo-Carbonifère de Surroca-Ogassa (province de Gérone, Espagne). In: 103e Congrès National des Sociétés Savantes, Nancy 1978: Sciences II. pp. 39-45.

Doubinger, J., Branchet, M., Langiaux, J., 1979. Présence de Callipteris flabellifera Weiss dans le Stéphanien de Blanzy-Montceau (Massif Central, France). Révue Period "La Physiophile". Soc. Etude Sci. Hist. Montceau-les-Mines 91, 69-74.

Erdtman, G., 1943. An Introduction to Pollen Analysis. Chronica Botanica Company, Waltham, Mass, pp. 238.

Faura, M., 1913. Síntesis estratigráfica de los terrenos primarios de la Cataluña, con una descripción de los yacimientos fosilíferos más principales. Memorias de la Real Sociedad Española de Historia Natural 9, 5-202.

Faura, M., 1914. Dictamen sobre las formaciones petrolíferas de San Juan de las Abadesas (Provincia de Gerona), que trata de explotar la "Compañía Española de Aceites de Esquisto, (S.A.)". In: Barcelona: Tip. A. Febrer, pp. 12.

Fielding, C.R., Frank, T.D., Isbell, J.L., 2008. The Late Paleozoic ice age - a review of current understanding and synthesis of global climate patterns. In: Fielding, C.R., Frank, T.D., Isbell, J.L. (Eds.), Resolving the Late Paleozoic Ice Age in Time and Space. vol. 441. pp. 343-354 Boulder: Geological Society of America Special Paper.

Gaggero, L., Gretter, N., Langone, A., Ronchi, A., 2017. U-Pb geochronology and geochemistry of late Palaeozoic volcanism in Sardinia (southern Variscides). Geosci. Front. 8, 1263-1284.

Galtier, J., Broutin, J., 1995. La flore de la Zone de transition de l'Autunien supérieur de Lodève. Sci. Géol. Bull. 48, 83-93.

Gand, G., Galtier, J., Garric, J., Teboul, P.-A., Pellenard, P., 2013. Discovery of an Autunian macroflora and lithostratigraphic re-investigation on the western border of the Lodève 
Permian basin (Mont Sénégra, Hérault, France). Paleoenvironmental implications. C.R. Palevol 12, 69-79.

García-López, S., Sanz-López, J., 2002a. A stratigraphic overview of the Cantabrian Devonian

(NW Spain). In: García-López, S., Bastida, F. (Eds.), Palaeozoic Conodonts from Northern

Spain, ECOS VIII. Cuadernos del Museo Geominero. vol. 1. pp. 51-59.

García-López, S., Sanz-López, J., 2002b. Devonian to Lower Carboniferous conodont

biostratigraphy of the Bernesga Vally section (Cantabrian Zone, NW Spain). In: García-

López, S., Bastida, F. (Eds.), Palaeozoic Conodonts from Northern Spain. ECOS

VIII. Cuadernos del Museo Geominero, vol. 1. pp. 163-206.

Gisbert, J., 1981. Estudio geológico-petrológico del Stephaniense-Pérmico de la sierra del

Cadí. In: Diagénesis y Sedimentología. [dissertation]. Universidad de Zaragoza,

Zaragoza (Spain).

Gisbert, J., 1983. El Pémico de los Pirineos Españoles. In: Martínez-Díaz, C. (Ed.),

Carbonífero y Pérmico de España. Publicaciones del Instituto Geológico y Minero de España, pp. 405-420.

Gómez-Alba, J., 2007. La cuenca carbonífera de Surroca-Ogassa (Ripollès, Cataluña,

España). Historia económica, minera y geológica y catálogo de la flora carbonífera

catalana del Museu de Ciències Naturals de Barcelona. Monografies del Museu de

Ciències Naturals 4, 1-263.

Gretter, N., Ronchi, A., López-Gómez, J., Arche, A., De la Horra, R., Barrenechea, J., Lago,

M., 2015. The Late Palaeozoic-Early Mesozoic from the Catalan Pyrenees (Spain): 60Myr of environmental evolution in the frame of the western peri-Tethyan pa- laeogeography.

Earth Sci. Rev. 150, 679-708.

Gulbranson, E.L., Montañez, I.P., Tabor, N.J., Limarino, C.O., 2015. Late Pennsylvanian

aridification on the southwestern margin of Gondwana (Paganzo Basin, NW Argentina): a regional expression of a global climate perturbation. Palaeogeogr.

Palaeoclimatol. Palaeoecol. 417, 220-235.

Isozaki, Y., 2009. Illawarra Reversal: the fingerprint of a superplume that triggered Pangean

breakup and the end-Guadalupian (Permian) mass extinction. Gondwana Res. 15, 421432.

Jongmans, W.J., 1951. Las floras carboníferas de España. Estud. Geol. 7, 281-330.

Kerp, H., 1996. Post-Variscan Late Palaeozoic Northern Hemisphere gymnosperms: the

onset to the Mesozoic. Rev. Palaeobot. Palynol. 90, 263-285.

Kerp, H., Flchter, J., 1985. Die Makrofloren des saarpfälzischen Rotliegenden (?Ober-

Karbon - Unter-Perm; SW-Deutschland). Mainz. Geowiss. Mitt. 14, 159-286.

Knight, J.A., Wagner, R.H., 2014. Proposal for recognition of a Saberian Substage in the mid-Stephanian (West European chronostratigraphic scheme). Freib. Forsch. c548,

179-195.

Lemoigne, Y., Doubinger, J., 1984. Réflexion sur la coexistence de flores hygrophile, mésophile et mésoxérophile durant le Paléozoïque Supérieur en Euramérie. Geobios 17, 365-369.

Lloret, J., Ronchi, A., López-Gómez, J., Gretter, N., De la Horra, R., Barrenechea, J.F., Arche, A., 2018. Syn-tectonic sedimentary evolution of the continental late Palaeozoicearly Mesozoic Erill Castell-Estac Basin and its significance in the devel- opment of the central Pyrenees Basin. Sediment. Geol. 374, 134-157. https://doi.

org/10.1016/j.sedgeo.2018.07.014.

Looy, C.V., Kerp, H., Duijnstee, I.A.P., Dimichele, W.A., 2014. The Late Paleozoic ecological-evolutionary laboratory, a land-plant fossil record perspective. Sediment. Rec. 12, 4-10.

Lucas, S.G., Shen, S.-Z., 2018. The Permian timescales: an introduction. In: Lucas, S.G., 
Shen, S.Z. (Eds.), The Permian Timescale. London: Geological Society Special Publications, vol. 450. pp. 1-19.

Luthardt, L., Rößler, R., Schneider, J.W., 2016. Palaeoclimatic and site-specific conditions in the Early Permian fossil forest of Chemnitz. Sedimentological, geochemical and palaeobotanical evidence. Palaeogeogr. Palaeoclimatol. Palaeoecol. 441, 627-652.

Martí, J., 1986. El Vulcanisme Explosiu del Tardihercinià del Pirineu Català. [disserta- tion]. Universitat de Barcelona, Barcelona (Spain).

Martín-Closas, C., Galtier, J., 2005. Plant taphonomy and paleoecology of Late Pennsylvanian intramontane wetlands in the Graissessac-Lodève basin (Languedoc, France). PALAIOS 20, 249-265.

Martín-Closas, C., Martínez-Roig, D., 2007. Plant taphonomy and palaeoecology of Stephanian limnic wetlands in the eastern Pyrenees (Catalonia, Spain). C.R. Palevol 6, 437-449.

Mendez, C.A., 2006. Upper Moscovian-middle Kasimovian conodonts (Pennsylvanian, Carboniferous) from the Las Llacerias Section (Cantabrian Zone, north Spain). Geobios 39, 245-254.

Menéndez Amor, J., 1952. Algunas plantas fósiles permianas de la provincia de Lérida. Notas y Comunicaciones Instituto Geológico y Minero de España 28, 117-123.

Mey, P.H.W., Nagtegaal, P.J.C., Roberti, K.J., Hartevelt, J.J., 1968. Lithostratigraphic subdivision of post-Variscan deposits in the South-Central Pyrenees, Spain. Leidse. Geol. Meded. 41, 221-228.

Michel, L.A., Tabor, N.J., Montañez, I.P., Schmitz, M.D., Davydov, V.I., 2015.

Chronostratigraphy and Paleoclimatology of the Lodève Basin, France: evidence for a pantropical aridification event across the Carboniferous-Permian boundary.

Palaeogeogr. Palaeoclimatol. Palaeoecol. 430, 118-131.

Mitjavilla, J., Molist, J.M., 1988. El volcanismo tardihercínico del Pirineo catalán, II:

caracterización de la actividad explosiva. Acta Geol. Hisp. 23, 21-32.

Montañez, I.P., Tabor, N.J., Niemeier, D., Dimichele, W.A., Frank, T.D., Fielding, C.R., Isbell,

J.L., 2007. CO2-forced climate and vegetation instability during Late Paleozoic deglaciation. Science 315, 87-91.

Montañez, I.P., McElwain, J.C., Poulsen, C.J., White, J.D., Dimichele, W.A., Wilson, J.P., Griggs, G., Hren, M.T., 2016. Climate pCO2 and terrestrial carbon cycle linkages during late Palaeozoic glacial-interglacial cycles. Nat. Geosci. 9, 824-831.

Mujal, E., Fortuny, J., Oms, O., Bolet, A., Galobart, À., Anadón, P., 2016a.

Palaeoenvironmental reconstruction and early Permian ichnoassemblage from the NE Iberian Peninsula (Pyrenean Basin). Geol. Mag. 153, 578-600.

Mujal, E., Gretter, N., Ronchi, A., López-Gómez, J., Falconnet, J., Diez, J.B., De la Horra, R., Bolet, A., Oms, O., Arche, A., Barrenechea, J.F., Steyer, J.-S., Fortuny, J., $2016 b$.

Constraining the Permian/Triassic transition in continental environments: Stratigraphic and paleontological record from the Catalan Pyrenees (NE Iberian Peninsula). Palaeogeogr.

Palaeoclimatol. Palaeoecol. 445, 18-37.

Mujal, E., Fortuny, J., Pérez-Cano, J., Dinarès-Turell, J., Ibáñez-Insa, J., Oms, O., Vila, I., Bolet, A., Anadón, P., 2017. Integrated multi-stratigraphic study of the Coll de Terrers late Permian-Early Triassic continental succession from the Catalan Pyrenees (NE Iberian Peninsula): a geologic reference record for equatorial Pangaea. Glob. Planet. Chang. 159, 46-60.

Mujal, E., Fortuny, J., Marmi, J., Dinarès-Turell, J., Bolet, A., Oms, O., 2018. Aridification across the Carboniferous-Permian transition in central equatorial Pangea: the Catalan Pyrenean succession (NE Iberian Peninsula). Sediment. Geol. 363, 48-68.

Nagtegaal, P.J.C., 1969. Sedimentology, paleoclimatology, and diagenesis of post-

Hercynian continental deposits in the south-central Pyrenees, Spain. Leidse. Geol. Meded. 42, 143-238. 
Ogg, J.G., Ogg, G., Gradstein, F.M., 2016. Chapter 9: Carboniferous. In: Ogg, J.G., Ogg, G., Gradstein, F.M. (Eds.), A concise Geologic Time Scale 2016. Elvise, pp. 99-113.

Opluštil, S., Schmitz, M., Cleal, C.J., Martínek, K., 2016a. A review of the Middle-Late Pennsylvanian west European regional substages and floral biozones, and their correlation to the Geological Time Scale based on new U-Pb ages. Earth Sci. Rev. 154, 301335.

Opluštil, S., Schmitz, M., Kachlík, V., Štamberg, S., 2016b. Re-assessment of lithostratigraphy, biostratigraphy, and volcanic activity of the Late Paleozoic Intra-Sudetic, Krkonoše-Piedmont and Mnichovo Hradiště Basins (Czech Republic) based on new U- Pb CA-ID-TIMS ages. Bull. Geosci. 91, 399-432.

Opluštil, S., Jirásek, J., Schmitz, M., Matýsek, D., 2017. Biotic changes around the radiosotopically constained Carboniferous-Permian boundary in the Boskovice Basin (Czech Republic). Bull. Geosci. 92, 95-122.

Owens, B., Turner, N., 1995. Late Westphalian palynomorphs from northern Saudi Arabia. Rev. Palaeobot. Palynol. 89 (1-2), 125-137.

Paquette, Y., Doubinger, J., Courel, L., 1980. Étude palynologique de la couche du toit du bassin autunien de l'Aumance (Assise de Buxières); liaison avec des milieux sédimentaires. Bull. Soc. Hist. Natur. Autun 95, 85-101.

Pellenard, P., Gand, G., Schmitz, M., Galtier, J., Broutin, J., Stéyer, J.-S., 2017. Highprecision $\mathrm{U}-\mathrm{Pb}$ zircon ages for explosive volcanism calibrating the NW European continental Autunian stratotype. Gondwana Res. 51, 118-136.

Pereira, M.F., Castro, A., Chichorro, M., Fernández, C., Díaz-Alvarado, J., Martí, J., Rodríguez, C., 2014. Chronological link between deep-seated processes in magmachambers and eruptions: Permo-Carboniferous magmatism in the core of Pangaea (Southern Pyrenees). Gondwana Res. 25, 290-308.

Pittau, P., Del Rio, M., 2002. Palynofloral biostratigraphy of the Permian and Triassic sequences of Sardinia. In: Cherchi, A., Corradini, C., Putzu, M.T. (Eds.), Sardinia Field TripPalaeontology and Stratigraphy, 1. Rendiconti della Società Paleontologica Italiana. vol. 1. pp. 93-110.

Pittau, P., Del Rio, M., 2004. Upper Carboniferous to Triassic terrestrial palynofloras of Sardinia: biostratigraphic, paleoclimatologic and paleophytogeographic implications. Geol. Soc. Am. Abstr. Programs 36 (4), 1-83.

Pittau, P., Barca, S., Cocherie, A., Del Rio, M., Fanning, M., Rossi, P., 2002. Le bassin Permien de Guardia Pisano (sud-ouest de la Sardaigne, Italie): palynostratigraphie, paléophytogéographie, corrélations et âge radiométrique des produits volcaniques associés. Geobios 35, 561-580.

Pittau, P., Del Rio, M., Funedda, A., 2008a. Relationships between plant communities characterization and basin formation in the Carboniferous-Permian of Sardinia. Boll. Soc. Geol. Ital. 127 (3), 637-653.

Pittau, P., Del Rio, M., Cotza, F., Ronchi, A., Santi, G., Gianotti, R., 2008b. Pennsylvanian miospore assemblages from the Bèdero Section, Varese, Italian Southern Alps. Rev. Micropaleontol. 51, 133-166.

Remy, W., Remy, R., 1968. Atlas wichtiger stratigraphischer Leit-und Charakerarten im euramerischen Florasbereich. Argumenta Palaeobotanica 1, 55-86.

Robles, S., Llompart, C., 1987. Analisis paleogeográfico y consideraciones paleoicnologicas del Pérmico Superior y Triasico Inferior en la transversal del rio Sebre (Alt Urgell, Pirineo de Lérida). Cuad. Geol. Iber. 11, 115-130.

Roscher, M., Schneider, J.W., 2006. Permo-Carboniferous climate: Early Pennsylvanian to Late Permian climate development of central Europe in a regional and global context. Geol. Soc. Lond., Spec. Publ. 265, 95-136.

Royer, D.L., 2014. Atmospheric CO2 and O2 during the Phanerozoic: tools, patterns, and impacts. Geochem. Treatise 6, 251-267. 
Sahney, S., Benton, M.J., Falcon-Lang, H.J., 2010. Rainforest collapse triggered Carboniferous tetrapod diversification in Euramerica. Geology 38, 1079-1082.

Saura, E., Teixell, A., 2006. Inversion of small basins: effects on structural variations at the leading edge of the Axial Zone antiformal stack (Southern Pyrenees, Spain). J. Struct. Geol. 28, 1909-1920.

Schmidt, G., 1931. Das Paläozoikum der spanischen Pyrenäen. Abhandlungen Gesellschaft der Wissenschaften Göttingen. Math.-Phys. KI. III (5), 980-1065 (Spanish translation, 1943: El Paleozoico del Pirineo español. Publicaciones alemanas sobre Geología de España II, 101-195.).

Schneider, J., Körner, F., Roscher, M., Kroner, U., 2006. Permian climate development periTethys area. The Lodeve basin, French Massif Central, compared in a European and global context. Palaeogeogr. Palaeoclimatol. Palaeoecol. 240, 161-183.

Simancas, J.F., Tahiri, A., Azor, A., Lodeiro, F.G., Martínez Poyatos, D.J., El Hadi, H., 2005.

The tectonic frame of the Variscan-Alleghanian orogen in Southern Europe and Northern

Africa. Tectonophysics 398, 181-198.

Soriano, C., Martí, J., Casas, J.-M., 1996. Palinspastic reconstruction of Permo-

Carboniferous basins involved in Alpine deformation: the Erill Castell-Estac basin,

Southern Pyrenees, Spain. Geol. Mijnb. 75, 43-55.

Soula, J.-C., Lucas, C., Bessiere, G., 1979. Genesis and evolution of Permian and Triassic basins in the Pyrenees by regional simple shear acting on older Variscan structures: field evidence and experimental models. Tectonophysics 58, T1-T9.

Stephenson, M.H., 2016. Permian palynostratigraphy: a global overview. In: Lucas, S.G.,

Shen, S.Z. (Eds.), The Permian Timescale. Geological Society, London, Special

Publications Vol. 450.

Sun, K.-Q., 2006. The Cathaysia Flora and the mixed Late Permian Cathaysian-Angaran

Floras in East Asia. J. Integr. Plant Biol. 48, 381-389.

Tabor, N.J., Poulsen, C.J., 2008. Palaeoclimate across the Late Pennsylvanian-Early Permian tropical palaeolatitudes: a review of climate indicators, their distribution, and relation to palaeophysiographic climate factors. Palaeogeogr. Palaeoclimatol.

Palaeoecol. 268, 293-310.

Talens, J., Wagner, R.H., 1995. Stratigraphic implications of late Carboniferous and early Permian megafloras in Lérida, south-central Pyrenees; comparison with the Cantabrian Mountains. Coloquios de Paleontología, Universidad Complutense 47, 177-192.

Thomas, B.A., Cleal, C.J., 2017. Distinguishing Pennsylvanian-age lowland, extra- basinal and upland vegetation. Palaeobiodiver. Palaeoenviron. 97, 1-21.

Traverse, A.T., 2007. Paleopalynology, Second edition. Springer, Dordrecht, The Netherlands, pp. 814.

Wagner, R.H., 1984. Megafloral zones of the Carboniferous. In: Compte Rendu 9e Congrès International de Stratigraphie et Géologie du Carbonifère, Washington and

Champaign-Urbana 1979, 2. pp. 109-134.

Wagner, R.H., 2004a. Climatic changes as mirrored by Carboniferous and Permian floral distributions. Monografías del Jardín Botánico de Córdoba 11, 29-39.

Wagner, R.H., 2004b. Gondomaria grandeuryi (Zeiller) Wagner \& Castro, 1998, in the context of an upper Stephanian flora from Surroca (prov. Girona, Catalonia, Spain).

Treballs del Museu de Geologia de Barcelona 12, 53-67.

Wagner, R.H., Álvarez-Vázquez, C., 2010. The Carboniferous floras of the Iberian

Peninsula: a synthesis with geological connotations. Rev. Palaeobot. Palynol. 162, 239_ 324.

Wood, D.G., Gabriel, A.M., Lawson, J.C., 1996. Palynological techniques - processing and microscopy. In: Jansonius, J., McGregor, D.C. (Eds.), Palynology: Principles and

Applications. Vol. 1. AASP Foundation, pp. 29-50.

Ziegler, A.M., 1990. Phytogeographic patterns and continental configurations during the 
Permian Period. In: McKerrow, W.S., Scotese, C.R. (Eds.), Palaeozoic Palaeogeography and Biogeography. Geological Society, Memoir Vol. 12. pp. 363-379.

Ziegler, A.M., Scotese, C.R., McKerrow, W.S., Johnson, M.E., Bambach, R.K., 1979. Palaeozoic palaeogeography. Annu. Rev. Earth Planet. Sci. 7, 473-502. 